\title{
1 ANTS AS GEOMORPHOLOGICAL AGENTS: A GLOBAL ASSESSMENT
}

3 Heather A. Viles ${ }^{1}$, Andrew S. Goudie ${ }^{1}$, and Alice Goudie ${ }^{2}$

6

7

9

10

11

12

13

14

15

16

17

18

19

20

2. Emu Analytics, 1 St John's Lane, Farringdon, London EC1M 4BL, UK

10

1. School of Geography and the Environment, University of Oxford, South Parks Road, Oxford, OX1 3QY, UK

Heather.viles@ouce.ox.ac.uk; Andrew.goudie@stx.ox.ac.uk; agoudie57@hotmail.com 


\section{Abstract}

Ants are abundant in most of the world's terrestrial environments. They are energetic, strong for their size, numerous, and socially cooperative. They play many geomorphologically important roles. In particular, they construct mounds and subterranean galleries, create patterned ground, play a role in bioturbation, affect vegetation cover and soil properties (such as infiltration rate) and influence runoff and erosion. They also play roles in biogeochemical cycling and rock and mineral weathering. Here, we review and reanalyse data collected from over 80 studies on ant contributions to geomorphology from around the world. The clearest manifestation of the geomorphological role of ants is found in their various constructions, such as mounds. There can be hundreds or thousands of mounds per hectare, with a median density of $125 \mathrm{ha}^{-1}$ recorded in the studies reviewed. The longevity of these features varies and some are stable while others are highly erodible. The construction of mounds and galleries causes bioturbation (pedoturbation), a role which ants share with termites, worms and many mammals. A median rate of 1.5 tonnes $\mathrm{ha}^{-1} \mathrm{a}^{-1}$ is derived from the studies reviewed. Ants also produce patterned ground through their effects on vegetation. The relationships between ant activity and runoff and erosion are complex and not consistent. Bioturbation of soil, tunnelling activity, the construction of underground chambers, galleries and macro-pores, the removal and/or accumulation of organic material, and changes in vegetation cover, are all mechanisms by which ants might modify soil infiltration characteristics. Because of their effect on soil infiltration rates, sediment provision and on vegetation cover, ants can have a profound influence on runoff and soil movement on slopes. Only a modest amount of work has been done to investigate the role that ants play in rock weathering. Ants are greatly affected by human activities (especially land cover changes), 
and some geomorphologically-active species have proved to be highly invasive. The response of ants to future climate changes needs further investigation.

Key words: Mounds, bioturbation, patterned ground, infiltration, runoff, sediment yield

\section{Introduction}

Ants, which first appeared in the Cretaceous period (Wilson et al. 1967), and then became increasingly numerous in the Palaeogene and Neogene (Smith et al. 2011; LaPolla et al. 2013), are classified in a single family, the Formicidae, within the order Hymenoptera. There are around 15,000 known living species, though this figure is inexact and much debated. The actual number of extant species may well be two or three times this. We are far from having a complete inventory at the species level: Numerous ant species remain undiscovered and/or undescribed, especially from the tropics (Ward 2014; Lach et al. 2010). As Whitford and Eldridge (2013, p. 282) explained, 'Ants are abundant in most of the world's terrestrial environments from the tropics to the subarctic and from arid to extremely mesic areas.' They are, however, absent from Iceland, Greenland and Antarctica (Folgarait 1998; King 2016). Overall, species diversity of ants is greatest in the tropics (Economo et al. 2018) (Fig. 1). There are clear regional patterns of ant genera known to have geomorphological impacts, with Lasius, for example, being concentrated in the Northern Hemisphere, Pogonomyrmex restricted to North and South America, Atta only found in central and South America, Formica absent from South America and Australia and largely missing from Africa and South Asia. 
a

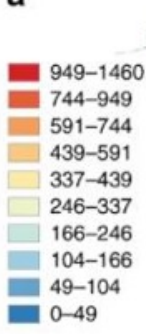

67

68

69

7

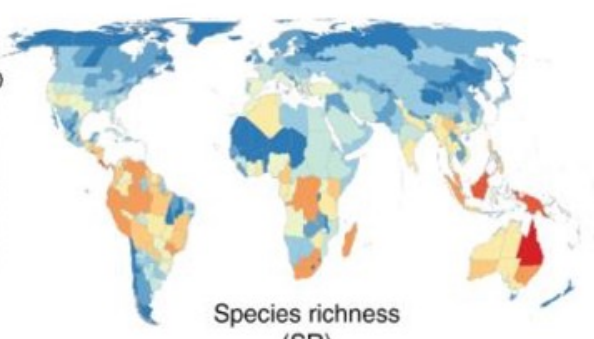

(SR)

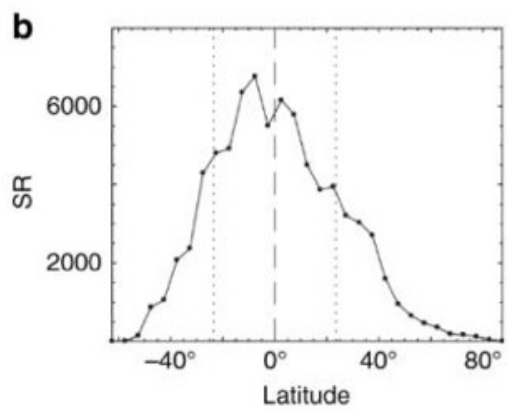

Fig. 1. a. Map of global ant species richness (SR). b. Ant species richness plotted against latitude (Source: Economo et al., 2018, figure 2).

One of the first people to recognise the geomorphological importance of ants was the Irish geologist, G.H. Kinahan (1869). He stated (p.348) that although they were so small, and, 'therefore, compared with the earth-worms, less capable, individually, of work', he saw that 'they are so numerous and energetic, that in the special places to which they resort, their yearly work is much more conspicuous than the annual worm-work; but the animals operate in different places, for while the earth-worm luxuriates in rich highly cultivated land, the hillbuilding-ant loves a dry, sandy or peaty soil'. Another early observer of the geomorphological importance of ants was the American geologist J.C. Branner (1910) who worked in Minas Geraes, Brazil, and noted that that the 'ant hills' were so dense, 'that the country looks like a field of gigantic potato hills' Branner (1900, p. 151)

Although they are small in size, with even so-called 'giant ants' such as Dinoponera and Myrmecia being no more than 30-50 $\mathrm{mm}$ in length, ants produce very large structures relative to their size. Whereas the size ratio of humans to the Great Pyramid of Giza is 1: 69 million, the ratio is 1: 5800 million for ants and in relation to the largest of their mounds. Equally their subterranean galleries require efforts 'which in magnitude may well be compared with those which excavated the catacombs of Rome' (McCook 1877, p. 271-272). McCook (1909) 
87 further noted the ability of ants to move pebbles vastly bigger and heavier than themselves. Individual ants can carry objects much greater than their own body weight (Andrews 1932), but even more significantly, and rarely in the animal world where only ants and humans seem to have this ability, they are capable of cooperative transport (i.e. they work together to move objects) (Czaczkes and Ratnieks 2013; Feinerman et al. 2018; Alma et al. 2020). Their efforts are matched by their numbers, for up to $10^{15}$ ants are estimated to live on Earth (Whitchurch 2014). Some ant species may occur in huge communities called super-colonies (Burchill and Moreau, 2016). A prime example is the Argentine ant Linepithema humile (formerly Iridomyrmex humilis) (Giraud et al., 2002).

The total global biomass of all ants may be broadly similar in magnitude to that of humans and termites, but less than that of earthworms, though accurate figures are hard to produce (see figures in https://en.wikipedia.org/wiki/Biomass_(ecology)). Tuma et al (2020) produce global estimates in terms of dry biomass (measured in Mtonnes of carbon), showing that ants account for 70, termites 50, all other terrestrial arthropods 80, Livestock 100, Humans 60, and wild terrestrial vertebrates 9.

Schultz (2000) suggested that on average, ants account for $15-20 \%$ of the terrestrial animal biomass, and in tropical regions where they are especially abundant, they account for $25 \%$ or more. Wilson and Hölldobler (2005) averred that although ant species make up 2\% of the known global insect species, they compose at least one-third of its biomass, and that in the Brazilian Amazon, the biomass of ants is approximately four times greater than that of all of the land vertebrates (mammals, birds, reptiles, and amphibians) combined. From studies in the eastern USA King et al. (2013) drew similar conclusions.

109 Non-arboreal, soil-dwelling ants play many geomorphologically important roles. In 110 particular, they construct mounds (Scott 1951) and subterranean galleries, create patterned 
ground, play a role in bioturbation, affect vegetation cover and soil properties (such as infiltration rate) and influence runoff and erosion. They also play roles in biogeochemical cycling and rock and mineral weathering. Not all ant species engage equally with these activities, for example many ants produce subsurface galleries and scatter the excavated material on the surface or within underground galleries rather than building mounds. Fig. 2 provides a conceptualisation of the interrelationships of the most important of these different geomorphological roles, which are caused by ant behaviours such as nesting, pupating, egg laying, sheltering, feeding, predation and fungus gardening. As well as these direct control in agricultural systems (Drummond and Choate, 2011).

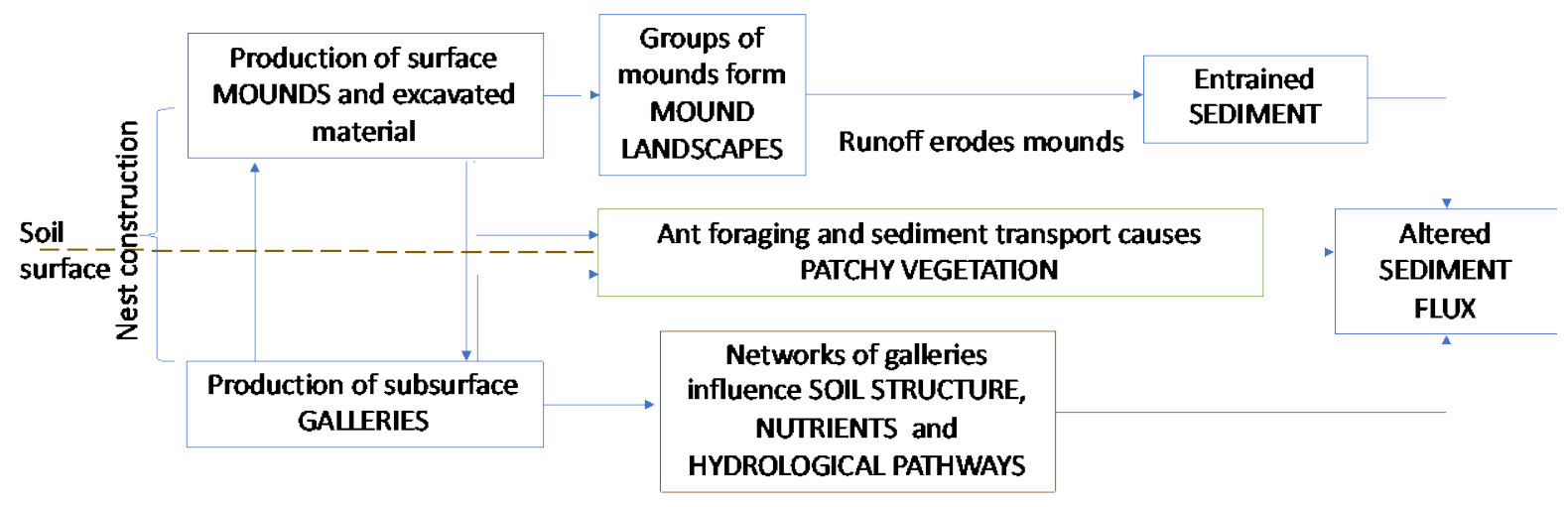

Fig.2. Conceptual diagram illustrating the main geomorphological consequences of nonarboreal ants and how they are interrelated.

127 When considering the relative importance of earth movement by humans in the Anthropocene compared to that achieved by natural processes, the role of small but numerous organisms such as ants, has often been ignored. Cooper et al. (2018), for example, estimate that human 
activities produced 316 Gt of sediment in 2015, whilst Syvitski and Kettner (2011) estimate that river-borne sediment delivery to oceans amounted to $15.1 \mathrm{Gt}$ pa (pre-human influence) and $12.8 \mathrm{Gt}$ pa (post-human influence). If each individual ant moved only $10 \mathrm{~g}$ of material each year, and assuming a global population of c. $10^{15}$ ants, c $10 \mathrm{Gt}$ of sediment could be produced by ants a year. The aim of this paper is to provide a global view of the geomorphological importance of ants, based on a review and reanalysis of published data with some additional newly collected data and informed by the Global Ant Biodiversity Informatics (GABI) geographical database (Guénard et al. 2017). In particular, we focus on collating information on the sizes and densities of ant mounds, the depths of underground ant nests, and the rates of bioturbation caused by the production of these features.

\section{Materials and methods}

Following a detailed review of published literature, a spreadsheet of data was produced, with each row representing a set of data on a particular species in a particular geographical location (see Supplementary Information). Comparable information on height and diameter of mounds (in $\mathrm{cm}$ ), density of mounds $\left(\mathrm{ha}^{-1}\right)$, depth of underground nest galleries (in $\mathrm{cm}$ ), and amount of soil moved in bioturbation/ mounding $\left(\mathrm{t} \mathrm{ha}^{-1} \mathrm{a}^{-1}\right)$ was extracted directly from the reviewed literature or, where necessary, calculated from the original data. Additional data was collected in the field and using remotely sensed imagery for a further 9 sites within the UK. Each site was geolocated as accurately as possible (latitude and longitude), and the relevant literature reference added. Where possible, the number of measurements taken from which the summary information was extracted was added (some studies only report on the dimensions of one single mound, whereas others have measured 100s of mounds, for example). For the main ant genera in the spreadsheet, the current known global diversity map was recorded using the interactive mapping tool on https://antmaps.org/ which allows visualisations of the GABI database (see Supplementary Information). 


\section{Results}

156 Our database (see Supplementary Information) contains 117 georeferenced sets of

157 quantitative data on the geomorphological roles of 62 individual species (as well as a few species only identified to genus level, and two mixed ant communities). The datasets come from more than 80 empirical studies, some of which studied multiple sites and/or ant species.

The 62 species come from 21 genera, with 16 species of Formica, 6 each of Atta, the world, with gaps in northern Eurasia, Southern Asia and much of Africa.

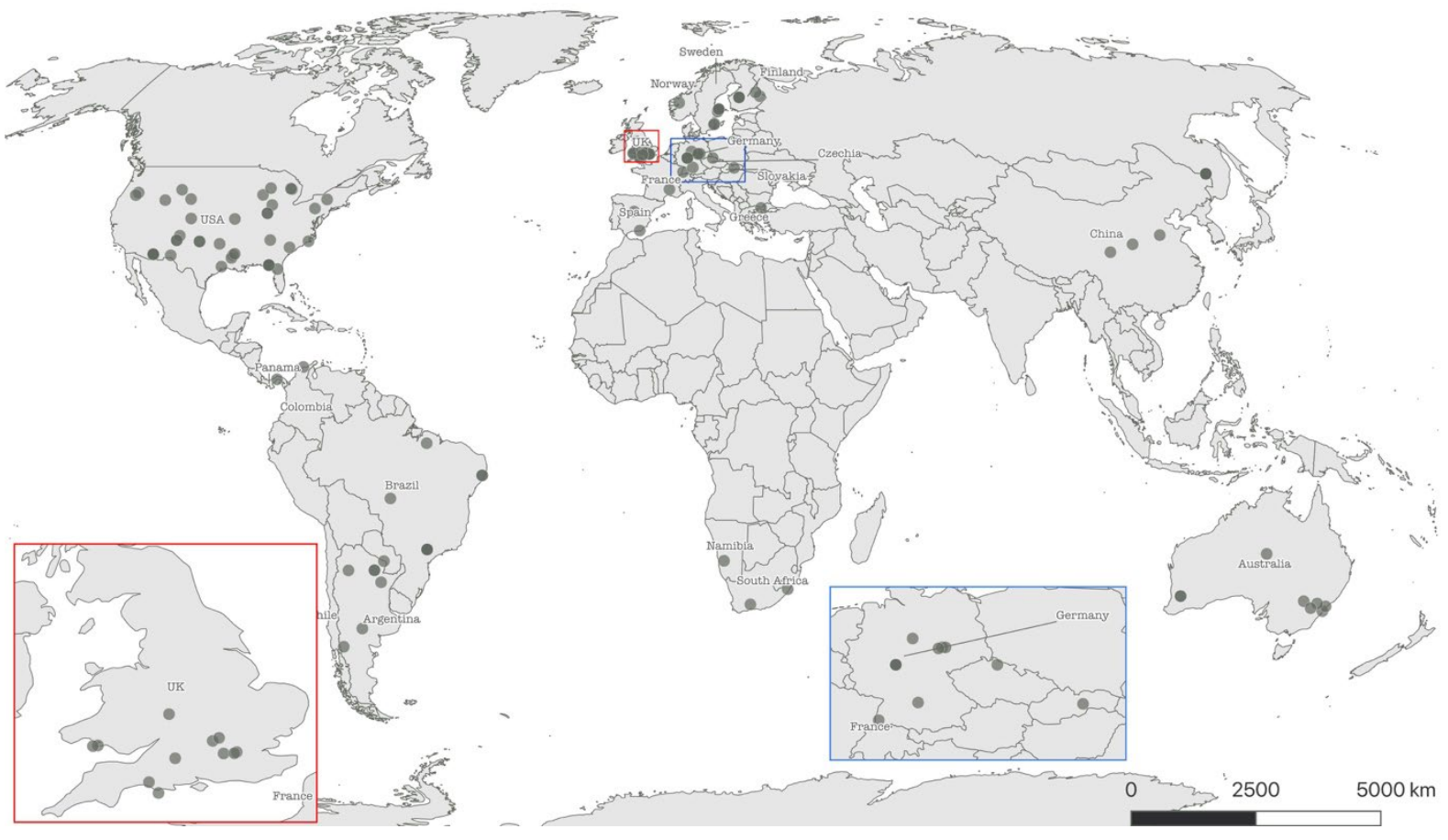

Fig. 3. Location of studies used to compile the ant geomorphology impacts database.

\subsection{Mounds}

167 The clearest manifestation of the geomorphological role of non-arboreal ants is found in their various constructions, such as mounds (often called hills), galleries (Thorp 1949), craters

169 (Wheeler and Wheeler 1983; Franks et al. 2004; Genise 2017) and turrets (Cosarinsky et al. 
2020). These create what Kováŕ et al. (2001) called 'antscapes' and Betard (2020) called 口 'moundscapes'. Where closely spaced they produce hummock and hollow topography, as in Montana, USA (Lesica and Kannowski 1998). The composition and shape of mounds varies between species (Wheeler and Wheeler 1983). Paton et al (1995) classify ant mounds into type 1 and type 2 categories, and type 2 can be further split into $2 \mathrm{a}$ and $2 \mathrm{~b}$. Type I consists of small, crater-shaped forms, rather like common earthworm casts, where soil material is deposited at the surface, and are susceptible to rapid erosion. The funnel-shaped mounds of Aphaenogaster ants are an example of this type (Richards 2009). Type II mounds are often larger features that are covered in vegetation and are more persistent through time. The latter type may be further subdivided into those largely composed of soil material (type IIa) such as those produced by ants from the genus Lasius, and those largely formed from organic material (e.g. pine needles, twigs, resin, bark, rabbit droppings), which are called type IIb mounds (Jurgensen et al. 2008). Organic mounds are often associated with the genus Formica. Both soil and organic material-dominated mounds are of geomorphological and pedological importance, albeit in different ways. Many mounds are composed of fine inorganic sediment (such as the 2-5 cm high and 10-40 cm diameter, easily erodible and often irregular-shaped mounds produced by Mycocepurus species (Rabeling et al. 2007), and others may be composed of coarser materials, such as granules, pebbles and the like. Harvester ants (e.g. Pogonomyrmex sp.) take coarse material (including human artefacts) to their mounds from many metres away (Spangler and Rettenmeyer 1966; Schoville et al. 2009).

Type 1 mounds are usually small and transient features, whereas type 2 mounds are usually larger and more permanent. Mounds vary hugely in shape from simple small conical or dome shapes to large complex forms topped by turrets for ventilation, as is the case with the leaf cutter Atta vollenweideri in the Chaco of Argentina (Cosarinsky and Roces 2012) and elsewhere (Halboth and Roces 2017). 
195

196

197

Fig. 4 summarises the frequency distributions of mound sizes in the database. Fig. 4a depicts a skewed distribution of mound heights found in 45 sets of measurements on 28 species $($ mean $=36 \mathrm{~cm}$, median $=29 \mathrm{~cm})$, with only two of $100 \mathrm{~cm}$ or greater - those produced by Atta vollenweideri and Solenopsis richteri (both recorded from Argentina). Fig. 4b illustrates a highly skewed distribution of mound diameters as reported in 52 sets of measurements on 33 species and one mixed community $($ mean $=136 \mathrm{~cm}$, median $=64 \mathrm{~cm})$ with few examples over $500 \mathrm{~cm}$ in diameter which are all produced by species from the genus Atta. Fig. 4c illustrates that the largest mounds are all found in South America. In summary, ant mounds can be as high as c $1.5 \mathrm{~m}$ and over $10 \mathrm{~m}$ in diameter, but are seldom more than $40 \mathrm{~cm}$ in height or $250 \mathrm{~cm}$ in diameter, so they are much less prominent features than the mounds constructed by termites, which on occasion can exceed $9 \mathrm{~m}$ in height (Goudie 1988).

a.

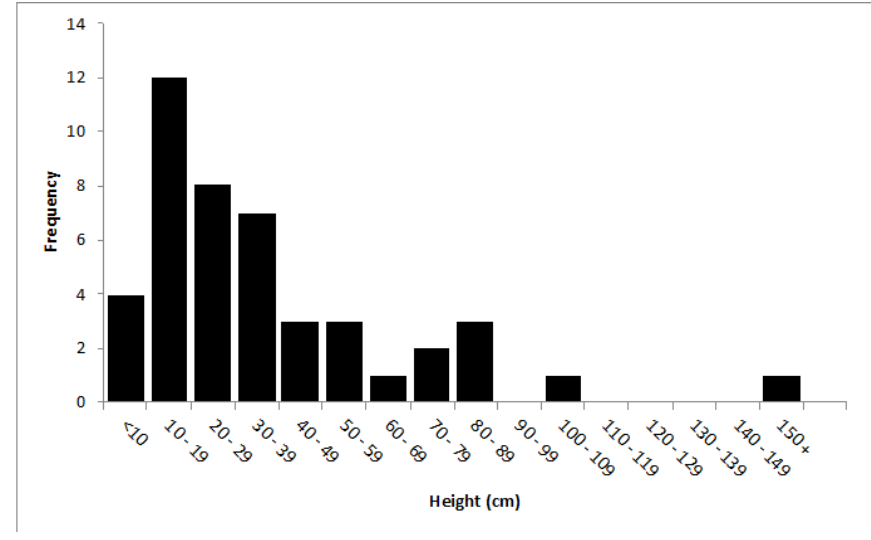

b.

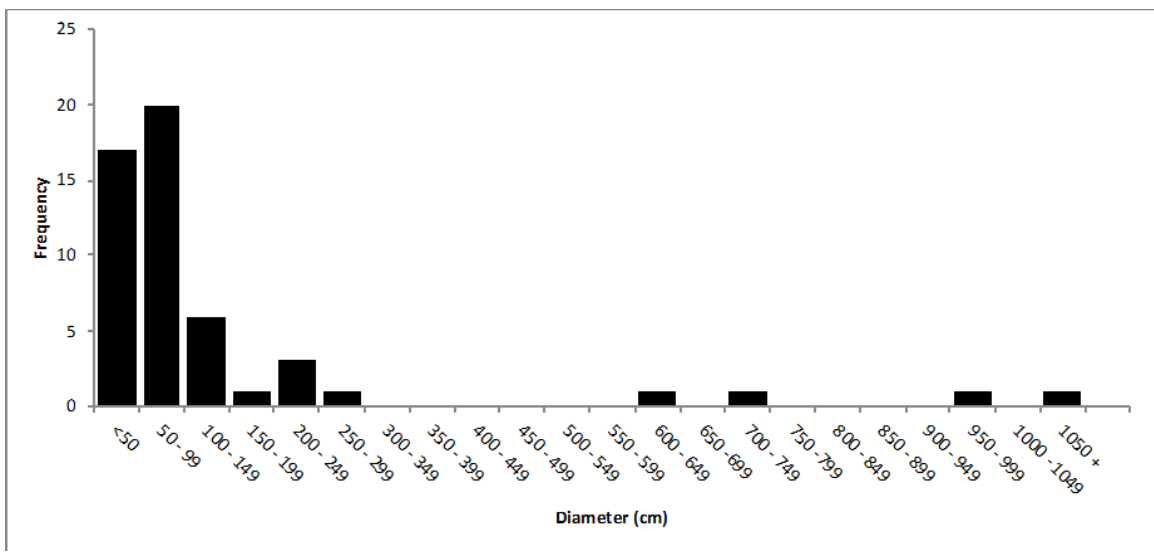




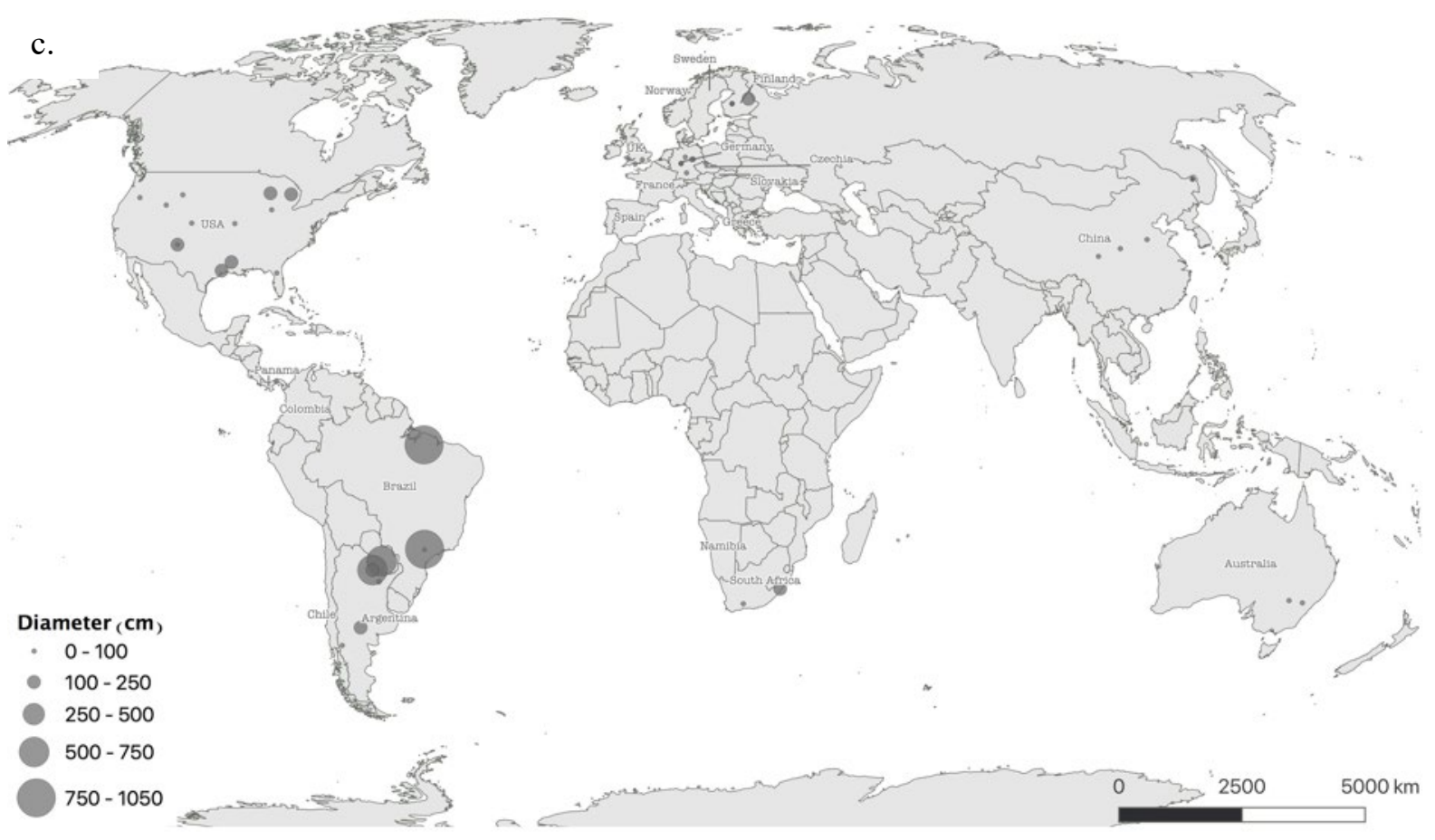

Fig.4 a. Histogram of ant mound heights $(\mathrm{cm}) \mathrm{b}$. Histogram of ant mound diameters $(\mathrm{cm}) \mathrm{c}$.

Map showing the locations of the data used in a. and b. (scaled according to diameter).

212 The mounds of some species are recorded as persisting for 50-100 years (e.g. those of Formica ulkeri as reported by Dreyer 1942; and those of Iridiomyrmex purpureus as studied by Cowan et al., 1985), although mounds can be abandoned by ants after much shorter periods. In England some Lasius flavus mounds have probably been occupied continuously for over 150 years (King 1981a). Cowan et al. (1985) suggested that the longevity of Iridomyrmex purpureus nests in New South Wales is around 100 years, while Dreyer (1942) suggested that Formica ulkei mounds in Illinois, USA had an average life span of 20-25 years. Henderson et al. (1989) found that Formica montana mounds were actively occupied for some decades. The mean life of harvester ant (Pogonomyrmex owyheei) nests in Idaho was c 17 years (Porter and Jorgensen, 1988). Tschinkel (2015) indicated that colonies of 
of some mounds is much less, and in South America Solenopsis richteri move their mounds on average every 3 months, on average $3 \mathrm{~m}$ away, and so might be able to affect $100 \%$ of the ground surface in a given landscape in 100 years (Green et al. 1999). Different nest turnover rates have been found in different studies. Swanson et al. (2019), for example, recorded nest turnover in Atta species as ranging from 11-27\% per year, whilst Klimetsek (1981) found that 31-38\% Formica rufa nests were abandoned per year between 1966 and 1978 in a 1640 ha area in the Black Forest, Germany, while over the same period annual rates of founding of new F. rufa nests varied between 32 and 60\%. Long-lived mounds can have significant impacts on sediment storage within geomorphological systems (Lobry de Bruyn and Conacher 1990), whilst ant species with high nest turnover rates can contribute greatly to sediment movement.

Mounds can occur in great profusion in certain environments. In a pioneering attempt at quantification, Scott (1951) reviewed the distribution of ant mounds in the western USA and noted that they are abundant across Wyoming, Utah, Colorado, Arizona, New Mexico, northwestern Texas, and the western portions of Nebraska, Kansas, and Oklahoma. He estimated that at least 3,000 square miles $\left(\mathrm{c} 7770 \mathrm{~km}^{2}\right)$ of the Wind River Basin, Wyoming, consists of flat upland benches or terraces which provide favourable habitats for the moundbuilding ants, and that a conservative estimate of three mounds per acre (approximately 7.5 mounds per hectare) resulted in an approximate total of 6 million mounds in this one basin. He suggested (p. 173) that they are the most active animal, other than humans, engaged in the transportation of soil in the semiarid regions of portions of the western USA.

Such initial estimates are confirmed by the density data from our database as shown in fig. $\mathbf{5}$. While many studies report mound densities, there are limitations with the data as different studies use different methods and calculate density over a very wide range of sampling area dimensions (ranging from a few $\mathrm{m}^{2}$ to several hectares). However, broad trends can be 
identified and as shown in fig. $\mathbf{5}$, in some locations there can be hundreds or thousands of mounds per hectare - with high densities in fig $5 \mathrm{~b}$ in Europe and Australia. The values for Lasius flavus (the yellow meadow ant) are particularly high, averaging $3933 \mathrm{ha}^{-1}$ for the

251 sixteen sites for which we have data.

a.
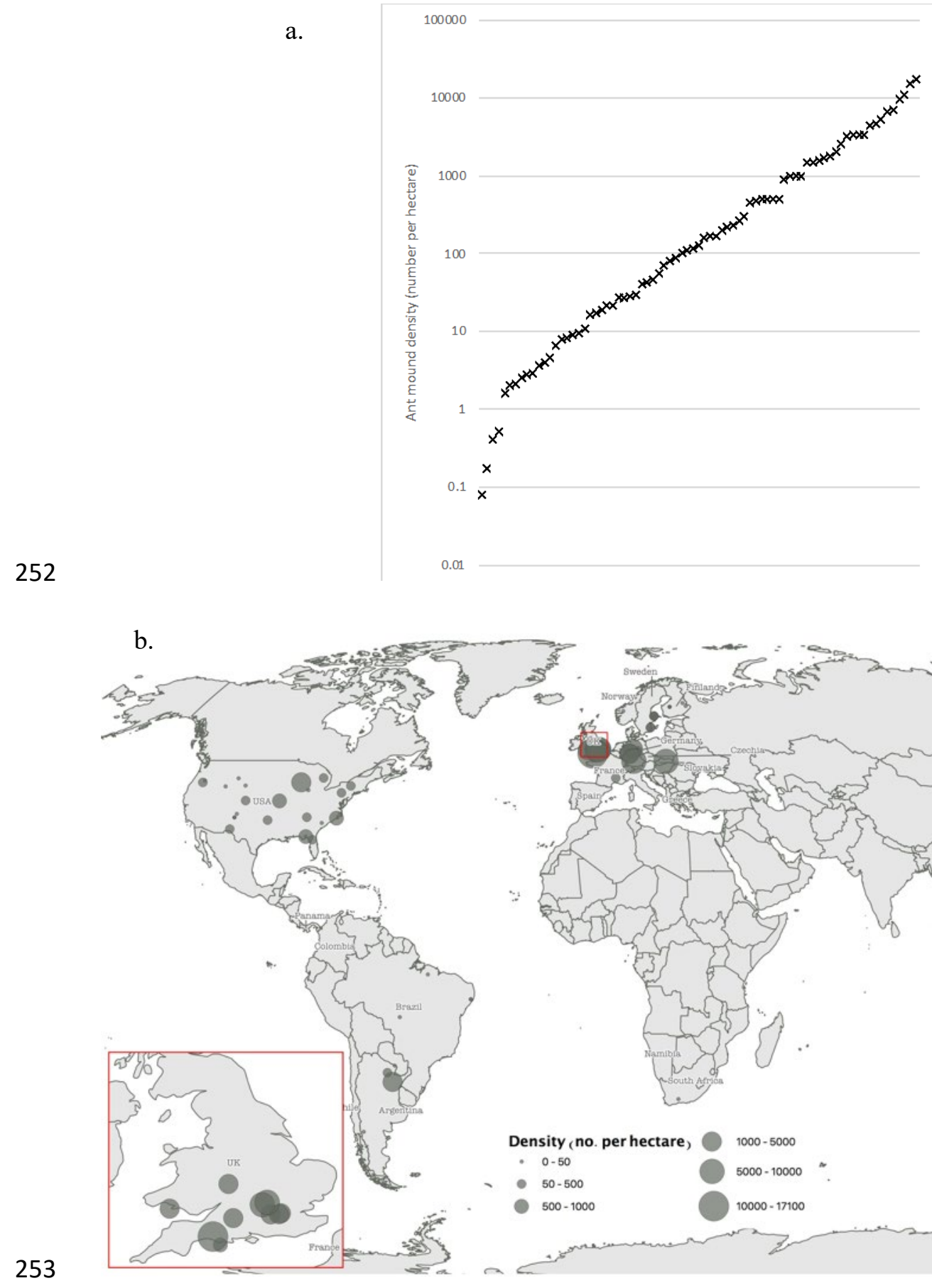
Fig.5. a. Ant mound densities (log scale) from 77 sets of measurements (mean density $=$ $1511 \mathrm{ha}^{-1}$, median $=125 \mathrm{ha}^{-1}, \min =0.08$ and $\left.\max =17100 \mathrm{ha}^{-1}\right) . \mathrm{b}$. Location of 77 sets of measurements, circles scaled by density.

Building on information on mound sizes and densities, several authors have made first order estimates of the percentage of land surface area affected. Cammeraat et al. (2002), for example, estimated that in Almeria, Spain, Messor bouvieri mounds cover c. $0.33 \%$ of the ground surface within a 48 x 28 m plot. In comparison, Moutinho et al (2002) mapped all Atta sexdens nests within a 25 ha plot in a regrowth forest in Brazil and calculated from density and size data that they covered $2 \%$ of the ground surface. More extensive coverage was recorded by Dostal et al (2005) who found Lasius flavus mounds to cover c. $13 \%$ of the ground surface within grasslands they sampled in a mountainous area in Slovakia. From these fragmentary estimates, ant mounds in densely covered areas appear to cover in the order of 0.5 and $15 \%$ of the ground surface.

Some ant species appear to be particularly important and widespread mound-builders. In the United Kingdom the prime mound builder is Lasius flavus, which is common on old chalk grasslands and elsewhere and creates type IIa mounds (Fig. 6). In Northamptonshire, central England, Pitt (1809) noted that on old grazing lands 'ant-hills were so abundant that it is possible to walk over many acres, step by step, from one ant-hill to another, without ever coming upon the level ground'. In the Gower peninsula of South Wales, mounds of this species are very widespread on acidic grasslands associated with the Old Red Sandstone (King 1981b). In south east England, at Silwood Park, mounds have developed on the Eocene beds (Waloff and Blackith 1962). This species also produces prominent mounds in Michigan, USA (Barton et al. 2009) and in central Germany (Bierbass et al. 2015). In the 
eastern USA an important mound builder is Formica exsectoides (Bristow et al. 1992), and Andrews (1925) reported a mound built by this species that contained more than a ton of earth. Other species are also capable of relocating large amounts of soil. Autori (1947, quoted in Costa-Milanez et al. 2017) estimated that Atta sexdens nests, constructed over an area of c $100 \mathrm{~m}^{2}$, can contain almost 40 tonnes of soil, whilst Folgarait (1998) calculated that construction.

a.

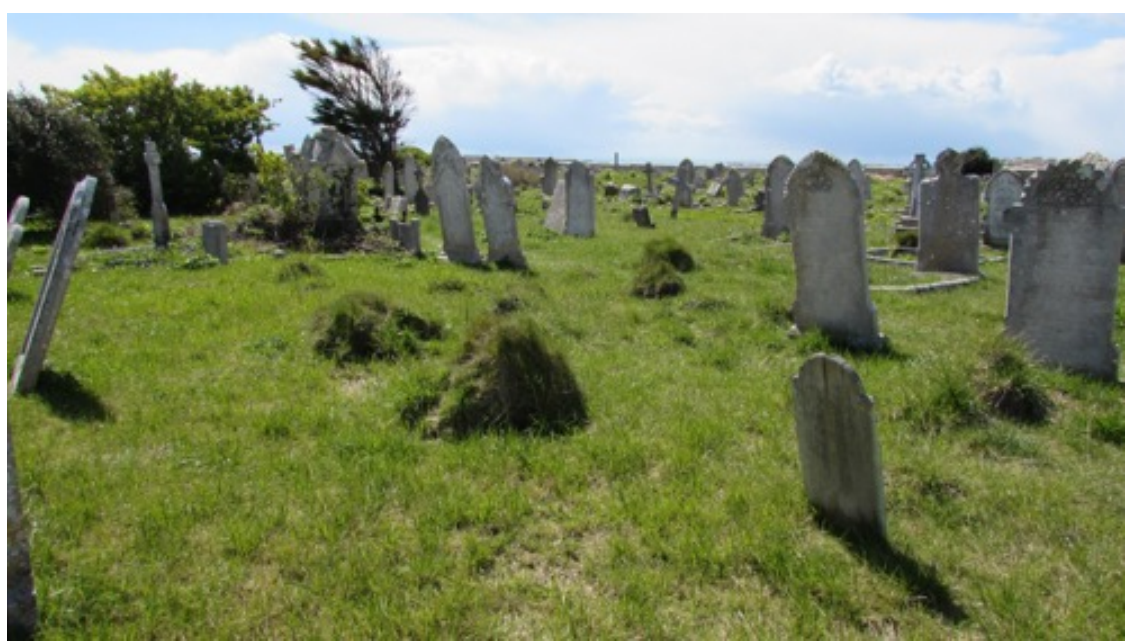

b.

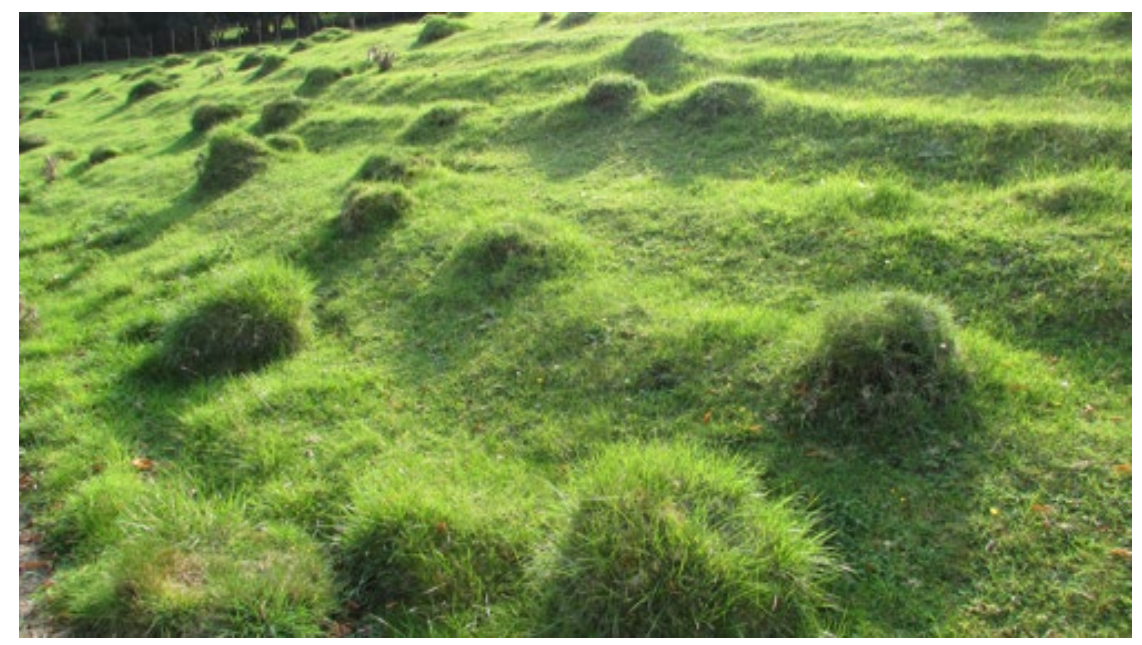

Fig. 6. Ant mounds built by Lasius flavus a. In the graveyard of St George's Church, 
Mound densities can vary greatly over small areas in response to differences in geomorphological situation. For example, in the Halle region of Germany, the density of mounds was (in mounds per ha), 3 for hilltops, 8 for valley bottoms, 78 for south-facing slopes and 101 for north-facing slopes (Dean et al. 1997). In the Chihuahuan Desert of the USA, Dugas (2001) found that Pogonomyrmex rugosa mounds occurred in greater densities close to arroyo edges rather than on the desert surfaces into which the arroyos were incised. Mound morphology varies according to soil composition, with mounds tending to be taller on clayey soils than on sandy ones (Green et al. 1999). Tall mounds may also be an important adaptation of ants to seasonally flooded or inundated soils (Whitford and Eldridge 2013) and mounds have even been observed on inter-tidal marsh surfaces (Jonathan Phillips, pers comm). In the boreal forest of Finland, Kilpeläinen et al. (2008) found that the density of ant mounds produced by Formica rufa group species varied with vegetation type, being highest under spruce and birch dominated forests, more frequent in old rather than young forests, and having the highest densities on fine sandy soils. They also found that the density declined towards the north of the country. Land use is another important control, and mounds tend to occur in low densities or not at all on frequently grazed or ploughed surfaces, whereas on ancient lightly grazed grasslands they can be very numerous. In southern England King (1981a) established that Lasius flavus mounds only started to develop when ploughing had ceased and that the largest hills occurred in the oldest grasslands. The unploughed grasslands of Richmond Park in south west London have over 400,000 Lasius flavus mounds, which have been built over the last four centuries since the area was created as a deer park by Charles 1. (http://www.timjking.co.uk/richmond-park.html) (accessed 26 ${ }^{\text {th }}$ September 2019) (Fig. 7). 

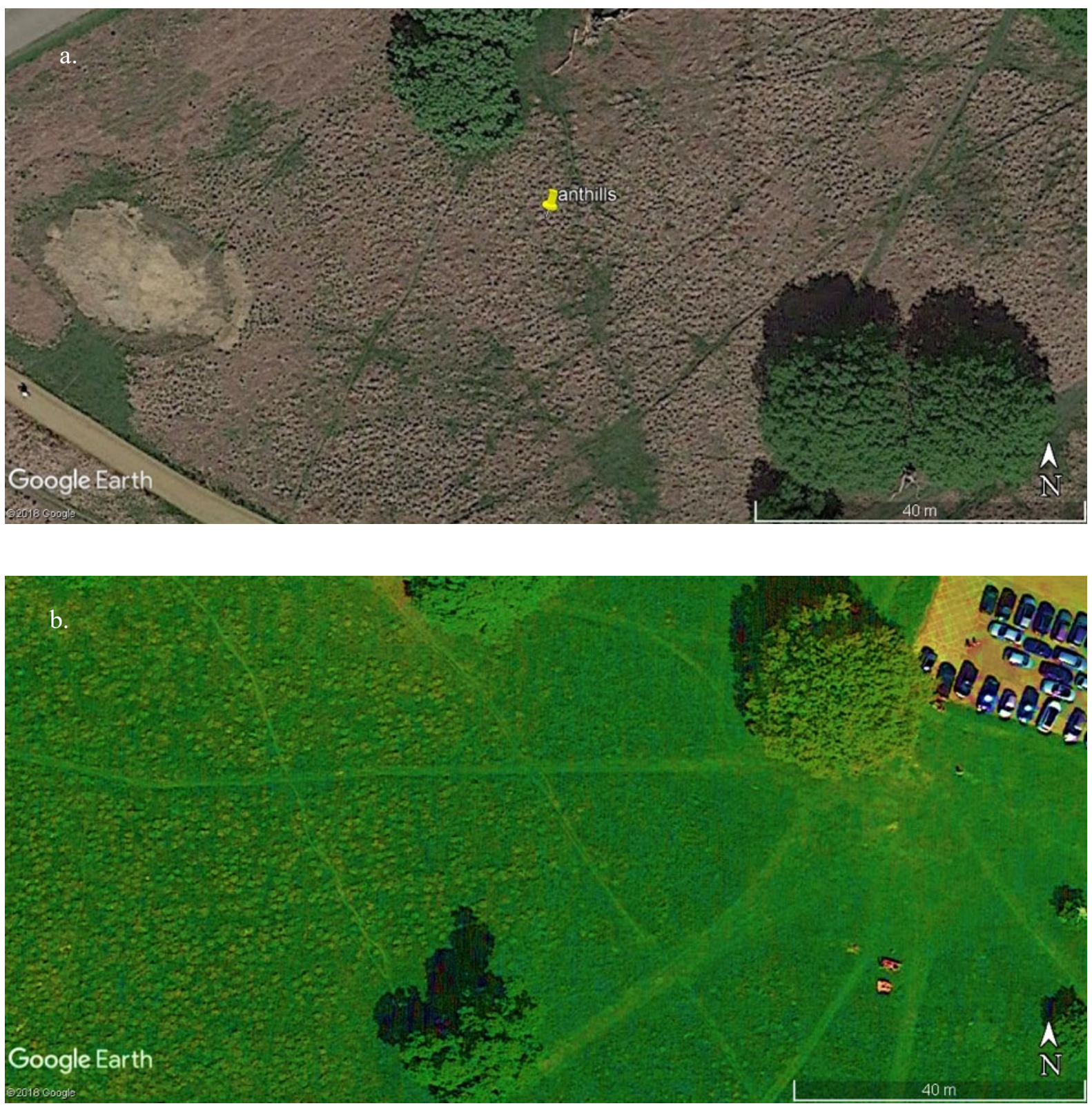

316 Fig. 7. a. Lasius flavus anthills in Richmond Park, London. Their density exceeds 400 per ha.

317 Courtesy of (C) Google Earth. Scale bar 40 m. b. Lasius flavus mounds in Bushy Park, London.

318 Courtesy of (C) Google Earth. Scale bar $40 \mathrm{~m}$.

320 In arid areas, mound or nest density tends to be greater at higher elevations and lowest at the

321 bottom of slopes that are prone to episodic flooding from upland runoff (Whitford and

322 Eldridge 2013, p. 283), while in North Carolina, Phillips (1999) found that specialized 
habitats at some forest-open-space boundaries resulted in concentrations of mound-building ants.

\subsection{Underground nests - galleries and tunnels.}

326

327

Many soil-dwelling ant species excavate impressively large and complex systems of galleries and tunnels. The construction of underground nests provides ants with protection against predators and unfavourable climatic conditions. Most ant species excavate nests and form a subterranean network of tunnels that connect several chambers. Such underground chambers are used to raise a brood, store seeds, grow fungus or accumulate litter and corpses. They may sometimes be used as resting places in which dense congregations of workers can be found. The tunnels ensure the connection of the underground parts of the nest to the soil surface (Gautrais et al. 2014).

Subterranean nests can be large and exhibit complex architecture, with many galleries and interconnecting tunnels. Several studies have carried out destructive sampling, using excavation and casting methods, to investigate these underground structures. For example, Moser (2006) excavated one Atta texana nest in northern Louisiana, and found 169 galleries, mainly less than $2 \mathrm{~m}$ below the soil surface, of which 97 were used for fungus gardens and 45 for storing detritus. Total nest volumes of 70-765 $\mathrm{cm}^{3}$ over depths of $15-66 \mathrm{~cm}$ have been recorded through casting studies of Camponotus socius nests in Florida (Tschinkel 2005). Casting studies on 25 Formica pallidefulva nests revealed shallow (30-45 cm deep) nests, with a very top heavy distribution of vertical shafts and chambers, and a strong correlation between nest volume and numbers of worker ants (Mikheyev and Tschinkel, 2004).

Excavations of 33 nests of Pogonomyrmex badius revealed similar top heavy architectures, with helical shafts 4-6 cm in diameter, and chambers $\mathrm{c} 1 \mathrm{~cm}$ in height to a depth of 2-3 $\mathrm{m}$. Nests contained between 5 and 150 chambers (Tschinkel, 2004). Three dimensional 
complexity in subterranean nests has been demonstrated by the study of Drager et al (2016)

who took detailed casts of two nests of Formica subserica in Kansas, illustrating multiple galleries down to $\mathrm{c} 70 \mathrm{~cm}$ below the surface, and extending up to $1 \mathrm{~m}$ away from the centre of the nest. A recent study by Pimentel-Farias et al (2020) recorded many characteristics of Atta bisphaerica ant colonies of different age, including external surface area, number of entrance holds, number and volume of chmabers, and numbers of worker ants. Over 4.5 years rapid expansion in dimensions and colony size was found (as summarised in table 1).

Table 1: Summary data on Atta bisphaerica subterranean nest dimensions at 2, 8 and 56 months (adapted from Pimentel-Farias et al (2020)

\begin{tabular}{|l|l|l|l|l|l|}
\hline Age & Number of & External & Depth (m) & Chamber & Number of \\
& nests & $\begin{array}{l}\text { surface area } \\
\left(\mathrm{m}^{2}\right) / \text { number } \\
\text { of entrance } \\
\text { holes }\end{array}$ & & volume (L) & worker ants \\
\hline 2 & 3 & $0.02(1)$ & 0.018 & $0.16(1)$ & 120 \\
\hline 8 & 4 & $0.036(1)$ & 0.90 & $0.7(2)$ & 700 \\
\hline 56 & 1 & $42(132)$ & 3.4 & $290(104)$ & 450,000 \\
\hline
\end{tabular}

357 Ants can burrow to depths as much as several metres depending on species, with rare examples known where depths extend to $32 \mathrm{~m}$ (e.g. Atta texana in Texas) (Moser 2006). Fig.

3598 summarises data on nest depths from 24 sets of measurements invoving 22 species, mainly in North and South America. The maximum depth recorded was $700 \mathrm{~cm}$, the minimum was 6 $\mathrm{cm}$, with a mean of $198 \mathrm{~cm}$ and a median of $146 \mathrm{~cm}$. 

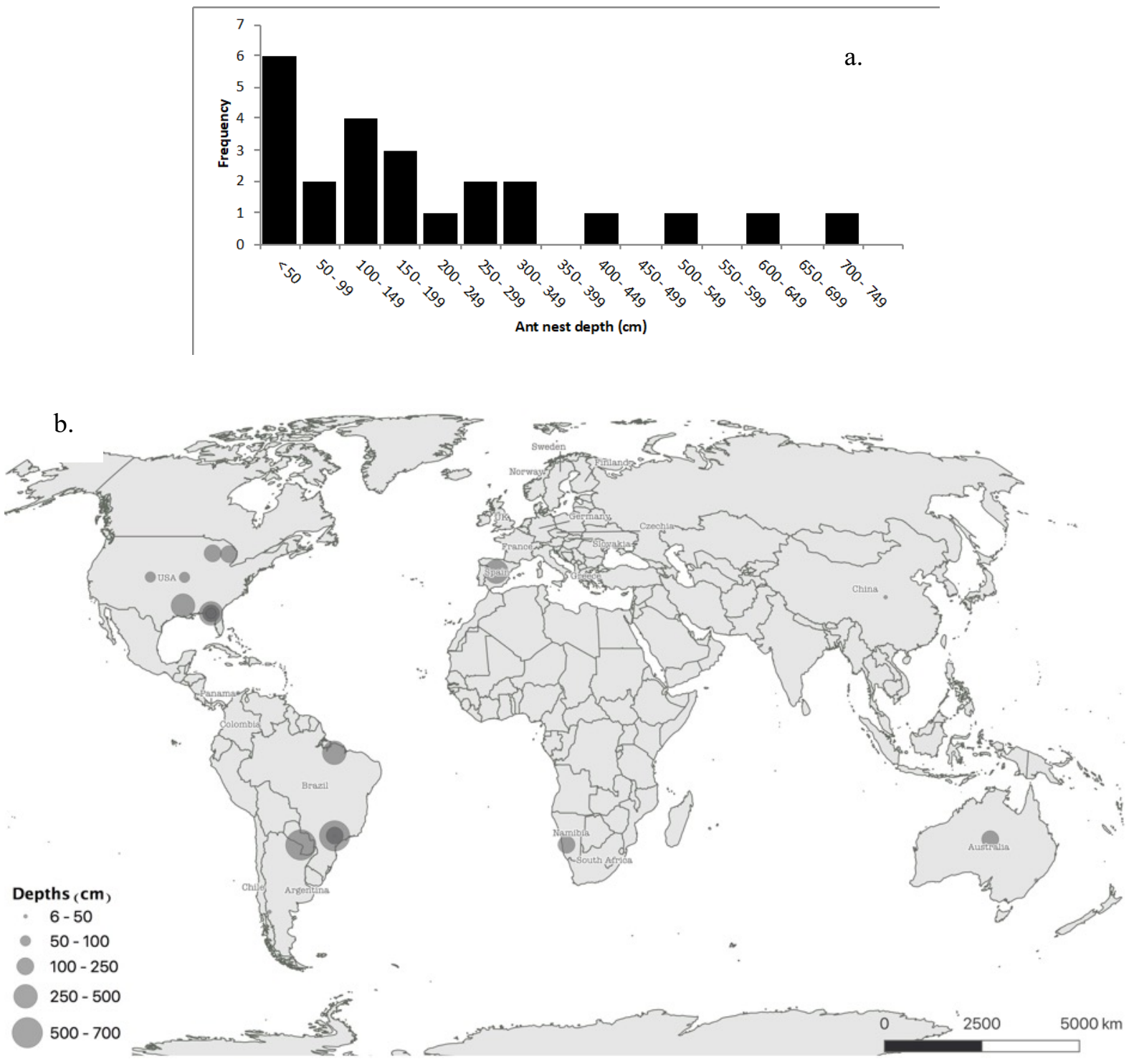

Fig. 8. a. Ant nest depths (cm) from 24 sets of measurements. b. Locations of the measurements used in a, scaled by depth.

\subsection{Bioturbation}

The construction of mounds and galleries causes bioturbation, a role which ants share with termites, worms and many mammals (Shaler 1892, pp. 277-281; Gabet et al. 2003; Blume 2014; Genise 2017). Many soils and surface regolith layers are biomantles (Johnson, 1990), created and maintained by the biomechanical effects of fauna and flora (Phillips 1999; 
372 Tschinkel and Seal 2016). However, as Richards (2009) pointed out, not all species of ant

373 contribute to bioturbation, and the propensity to build mounds and mix soil varies

374 enormously amongst those that do. Among the consequences of ant bioturbation are the

375 vertical movement of artefacts (e.g. Balek 2002; Robins and Robins 2011; Araujo 2013), the

376 sorting of sediment to produce stone (desert) pavements and stone lines (Leonard 2001), and

377 the disruption of depositional structures in dunes (Ahlbrandt et al. 1978). One implication of

378 such bioturbation is that it can affect the accuracy and appropriateness of OSL dating (Rink et

379 al. 2013).

380 The presence of mounds has been used as a basis for calculating the amount of ant bioturbation, but this leads to an underestimation of ant bioturbation activity. As Paton et al. (1995, p. 41) have pointed out, 'The difficulty with this is that ants do not invariably produce mounds, for by far the greatest number of ants' nests are excavated in soil under stones and logs without any recognizable superstructure.' Furthermore, species which move much soil material up the soil profile do not always deposit it on the surface in a mound - it can be stored within the underground nest.

Several different methods have been used to calculate mounding rates and bioturbation, and

fig. 9a summarises data from 25 sets of measurements on 17 species (and two mixed ant communities) from our database. The data are highly skewed (mean rate $=8.3$, median $=1.5$, $\left.\min =0.05, \max =68.38 \mathrm{tha}^{-1} \mathrm{a}^{-1}\right)$. Two rates of over $60 \mathrm{t} \mathrm{ha}^{-1} \mathrm{a}^{-1}$ were recorded, one from Aphaenogaster in Australia, and one from Pogonomyrmex in Florida, USA. Data were collected from a relatively wide array of genera, with a preponderance of studies in the USA, Europe and Australia (see fig. 9b). 

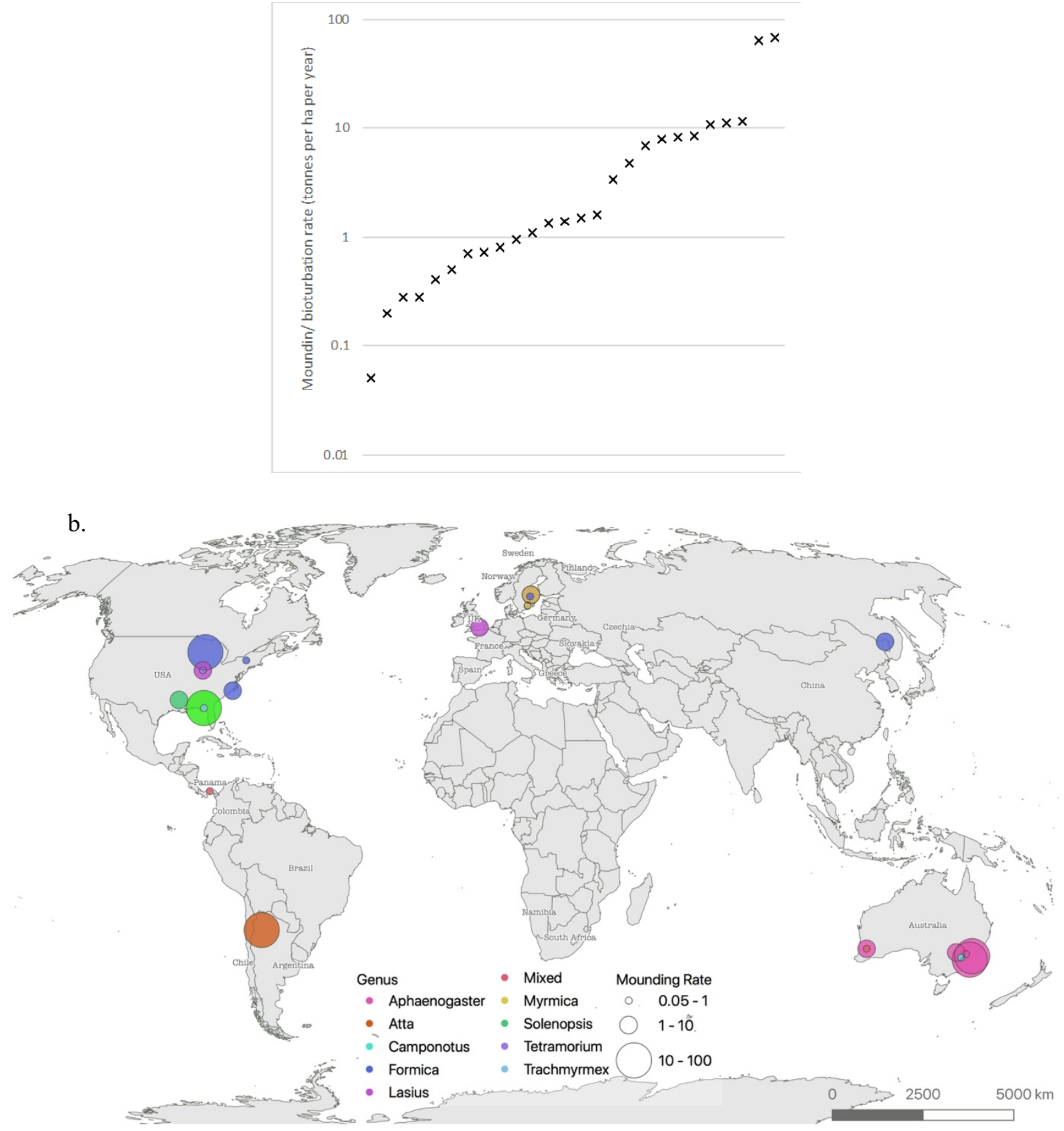

397 Fig. 9. a. Mounding/ bioturbation rates (tonnes $\mathrm{ha}^{-1} \mathrm{a}^{-1}$ ) from 25 sites (log scale), b. Locations of the sites coloured by genus and scaled by rate.

399 Data on bioturbation and mounding rates can be used to assess soil turnover times. For 400 example, Richards et al. (2011) suggested that for soils up to $30 \mathrm{~cm}$ deep, turnover times in 
south east Australia range from 300-100,000 years on different types of hill slope, with mounding rates for ants being almost as great as the rates achieved by vertebrates such as wombats. In North Carolina, USA, total mounding rates for Formica exsectoides in the edge zone between forest and non-forested areas amounted to $6.9 \mathrm{t} \mathrm{ha}^{-1} \mathrm{yr}^{-1}$ for the edge zone, which implies a soil turnover time for the upper $30 \mathrm{~cm}$ of soil of about 600 years (Phillips 1999). Lyford (1963), working on brown podzolic soils in New England, USA, found that a layer of soil material as much as 25 to $45 \mathrm{~cm}$ thick could be returned to the surface by ants in 3000-4000 years. Johnson and Johnson (2010), working in the mid west of the USA, estimated that two common ant species Lasius neoniger and Tetramorium caespitum alone contribute significantly to producing soil biomantle thicknesses of at least $90 \mathrm{~cm} / 1000$ years (equivalent to $9 \mathrm{~mm}$ per year).

Eight studies in our database use bioturbation and mounding rate data from 7 different species and one mixed ant community to calculate the depth of soil added across the surface (in $\mathrm{mm} \mathrm{a}^{-1}$ ), producing a mean of 0.28 , median of 0.09 , and a max of 0.86 . Five of the studies were carried out in the USA, two in Australia and one in Argentina. The maximum value came from a study of Lasius niger in Michigan, USA (Talbot, 1953 quoted in Paton et al. 1995).

There has long been discussion about whether rates of ant bioturbation are especially high and of greater relative importance in the tropics. This was the view of Branner (1900, p. 152) who wrote: 'The impression one gets from the work of ants along the line of the Bahia and Minas railway - and for that matter in other parts of the tropics - is that they are vastly more important geologic agents than the earthworms of temperate regions'. Earthworm biomass seems to be at its highest in regions such as the Eurasian steppes (Phillips et al. 2019), so it is perhaps not surprising that Taylor et al (2019) found that they were more important agents of 
bioturbation than ants in cold-temperate ecosystems. Tschinkel (2015) confirmed that

426

427

428 historically in the north temperate zone, ant bioturbation was regarded as achieving less than that achieved by worms, but he suggested that this was not necessarily the case in lower latitudes, where earthworm biomass tends to be lower. In Florida he indicated that Trachmyrmex septentionalis was the major bioturbator, depositing $0.5-1.5 \mathrm{t} \mathrm{ha}^{-1} \mathrm{yr}^{-1}$ on the ground surface. After a detailed review of bioturbation by a range of organisms, Wilkinson et al. (2009) made the following generalisations: (1) Ants are active mound builders in both moist and dry settings but their activity is generally considered to be much lower than that of earthworms. Most studies of ant bioturbation record $1-5 \mathrm{t} \mathrm{ha}^{-1} \mathrm{yr}^{-1}$ with a few studies recording 5-10 $\mathrm{t} \mathrm{ha}^{-1} \mathrm{yr}^{-1}(2)$ Termites mostly exhibit maximum mounding rates of $1-5 \mathrm{tha}^{-1}$ $\mathrm{yr}^{-1}$, i.e. similar to those of ants. (3) Rates of mounding by vertebrates are commonly $1-5 \mathrm{t}$ ha $^{-}$ ${ }^{1} \mathrm{yr}^{-1}$ (i.e. similar to those of ants and termites), though the most prodigious fossorial mammals such as pocket gophers and moles may mound at rates of $10-20 \mathrm{tha}^{-1} \mathrm{yr}^{-1}$.

The database provides only limited support for these suggestions that ants are particularly important in the tropics. The highest mounds and the deepest underground nests come from tropical and subtropical areas (figures 4 and 8), but mound densities appear particularly high in temperate regions (figure 5). Lack of data makes it impossible to draw any conclsuions about any climatic control on bioturbation/mounding rates (figure 9). Currently, there is not enough data available from a wide enough range of climatic zones to make clear statements about whether climate influences the geomorphological contribution of ants.

\subsection{Patterned ground - vegetation clearance}

Patterned ground can be produced from dense patterns of ant mounds, but ants can also produce patterned ground through their effects on vegetation. Several mound-building ant species clear vegetation at some distance around their nests, such as species from the genera 
Formica and Pogonomyrmex. Some ant species clear a large amount of vegetation from the

450

451

452

453

454

455

456

457

458

459

460

461

462

463

464

465

466

467

468

469

470

471

472

473

land surface by grazing, and some kill vegetation by injecting formic acid into plants near the mound. For example, harvester ants (Pogonomyrmex) clear vegetation in dry regions (Soulé and Knapp 1996) and their mounds are surrounded by large 'denuded discs' (Carlson and Whitford 1991). MacMahon et al. (2000) found that in the USA some areas, such as sagebrush communities in Oregon, had been cleared of up to nearly $20 \%$ of their cover. Porter and Jorgensen (1988), working in Idaho, and confirming the earlier observations by Sharp and Barr (1960), found that these same ants had cleared about $4 \%$ of the area.

However, in moister areas, where the vegetation cover is more complete, this role of ants is likely to be less significant. Pogonomyrmex owyheei produces gravel-armoured nests set within cleared vegetation discs. Soule and Knapp (1996) studied 30 Pogonomyrmex owyheei mounds in central Oregon and found cleared vegetation circle diameters of $2.75 \mathrm{~m}$ (mean) with a maximum of $5.92 \mathrm{~m}$. Sneva (1979) recorded cleared vegetation discs from the same species in eastern Oregon of between 0.9 and $9 \mathrm{~m}^{2}$ which, assuming they are roughly circular, gives diameters of c $1-3 \mathrm{~m}$. In the saltsage (Atriplex) rangelands of Idaho, Sharp and Barr (1960) described circular clearings of vegetation produced by Pogonomyrmex occidentalis and noted that they covered up to $8 \%$ of the surface area. Similar features, also produced by Pogonomyrmex occidentalis, were illustrated from Wyoming by Dibner et al. (2015) (Fig. 10a). In comparison, Sparavigna (2016a, b) found 'polka-dot' patterned ground (Fig. 10b) close to the Grand Canyon in Arizona that had been produced by Pogonomyrmex, and likened these to the fairy circles of Namibia (Fig. 10c). The Namibian circles have been the subject of great debate, and many hypotheses have been invoked to explain their origin (Getzin et al. 2019), including competitive plant interactions and the role of termites, but Picker et al. (2012) found a close association between colonies of the ant Anoplotepsis steingroveri, elevated levels of alkanes and alkenes in the soil, and circle development. In the 
474 savannas of Kenya, Darlington (2007) likened the 'arena nests' produced by Messor

475 cephalotes to the Namibian fairy circles. A final type of patterned ground that may be related

476 to ants are charcoal-filled pits developed in sandy soils in Belgium which may be the remains

477 of burnt-out organic mounds produced by Formica ants (Crombe et al. 2015).
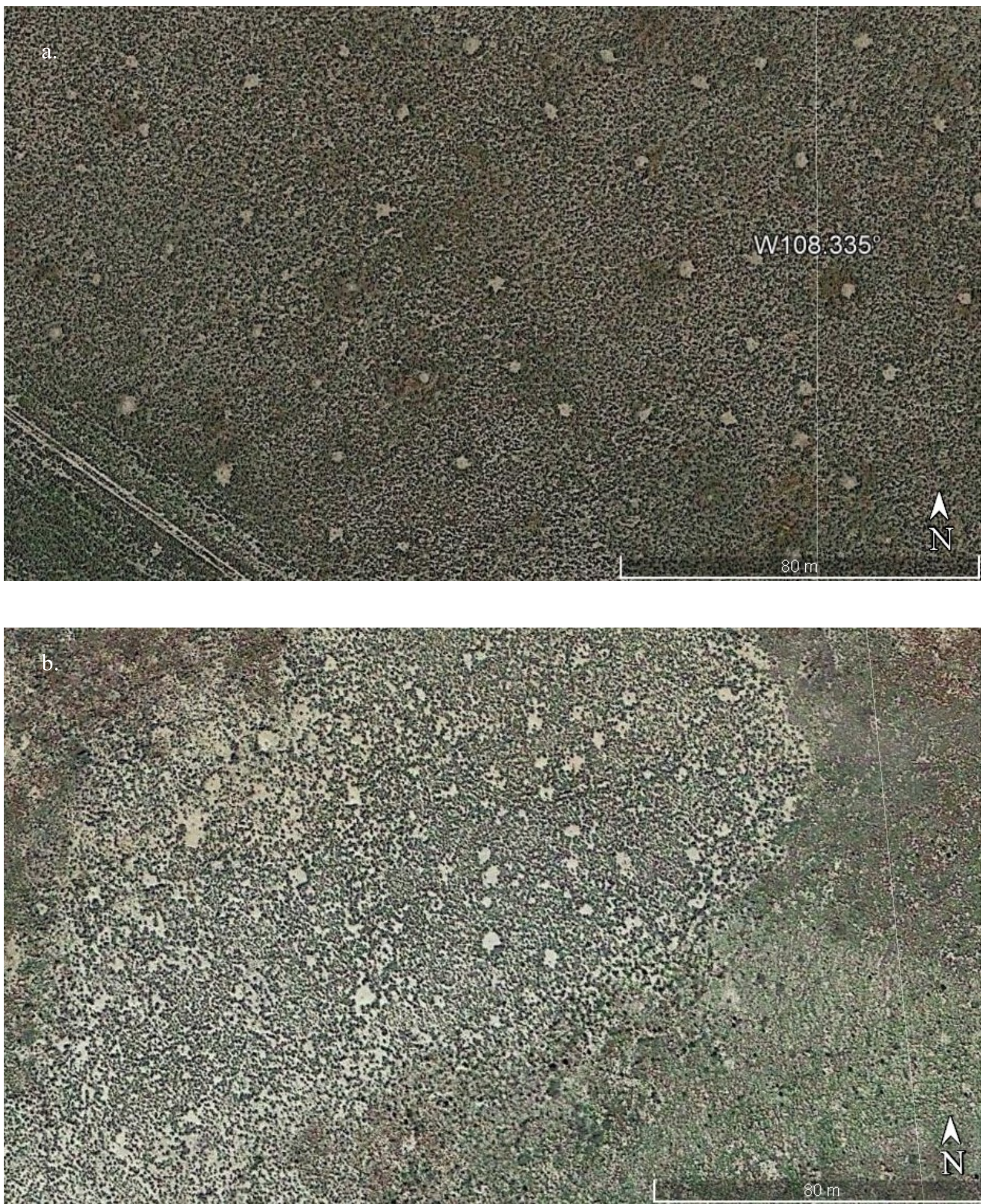


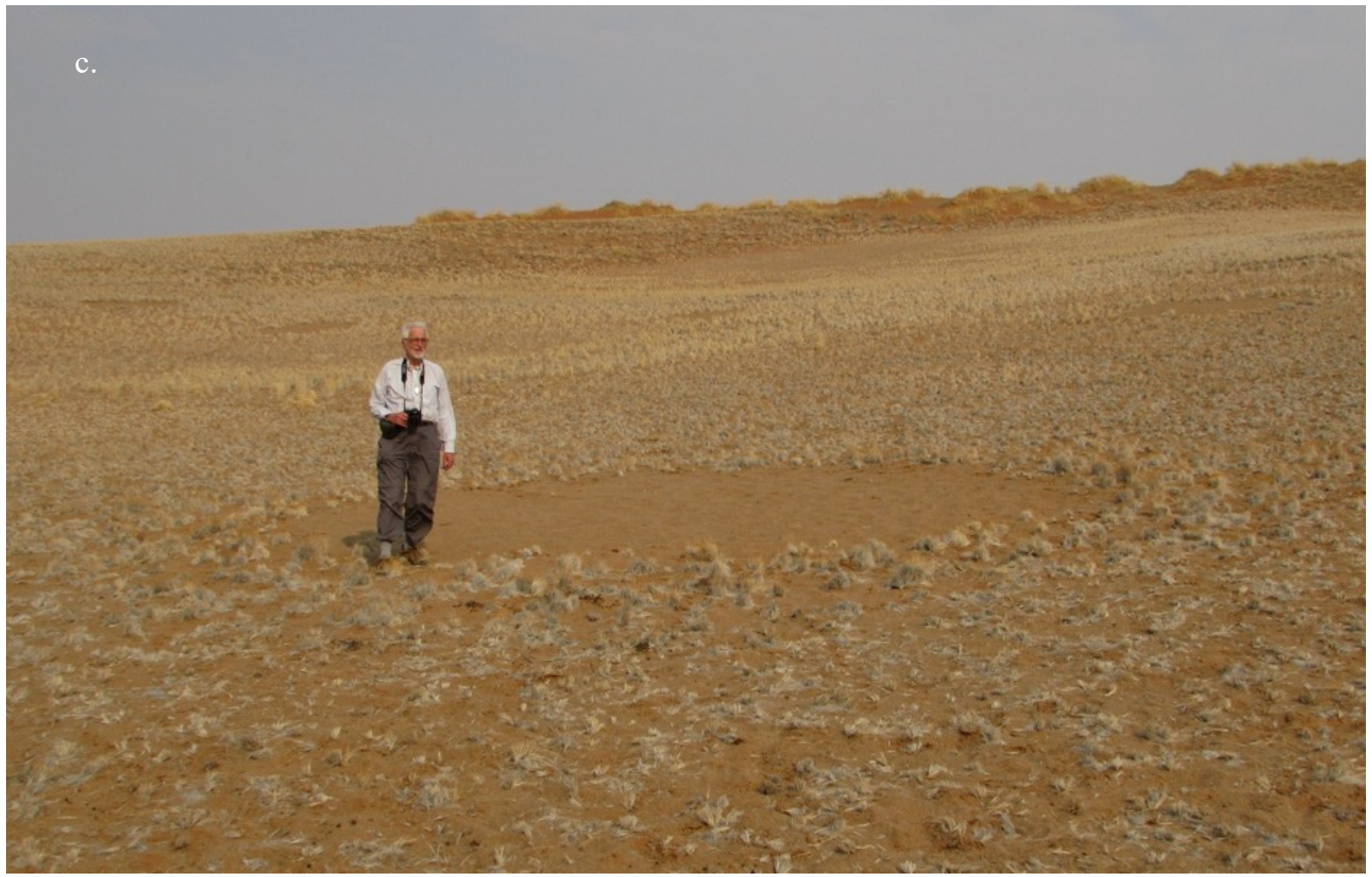

c

482 Fig. 10. a. Polka-dot features from near Riverton, Wyoming. Scale bar $80 \mathrm{~m}$. CCourtesy of 483 Google Earth, b. Polka-dot patterned ground close to the Grand Canyon, Arizona, that has 484 been produced by Pogonomyrmex. Scale bar 80 m. Location: c W113.072, N36.2916.

485 Courtesy of (CGoogle Earth, c. Fairy circle in Sossus Vlei, Namibia.

\subsection{Infiltration capacity}

487 Cammeraat and Risch (2008) found that most studies in their review had reported increased infiltration rates where ant burrows or mounds were present. Such increases have been observed in Iran (Ghobadi et al. 2016), the Cape Province of South Africa (Dean and Yeaton 1993), in eastern Australia, and in the loess plateau of China (Li et al. 2017; 2019). The relationships between ant activity, infiltration and runoff and erosion are complex and not consistent (Fig. 11). The bioturbation of soil, tunnelling activity (Buhl et al. 2006), the construction of underground chambers, galleries and macro-pores, the removal and/or 


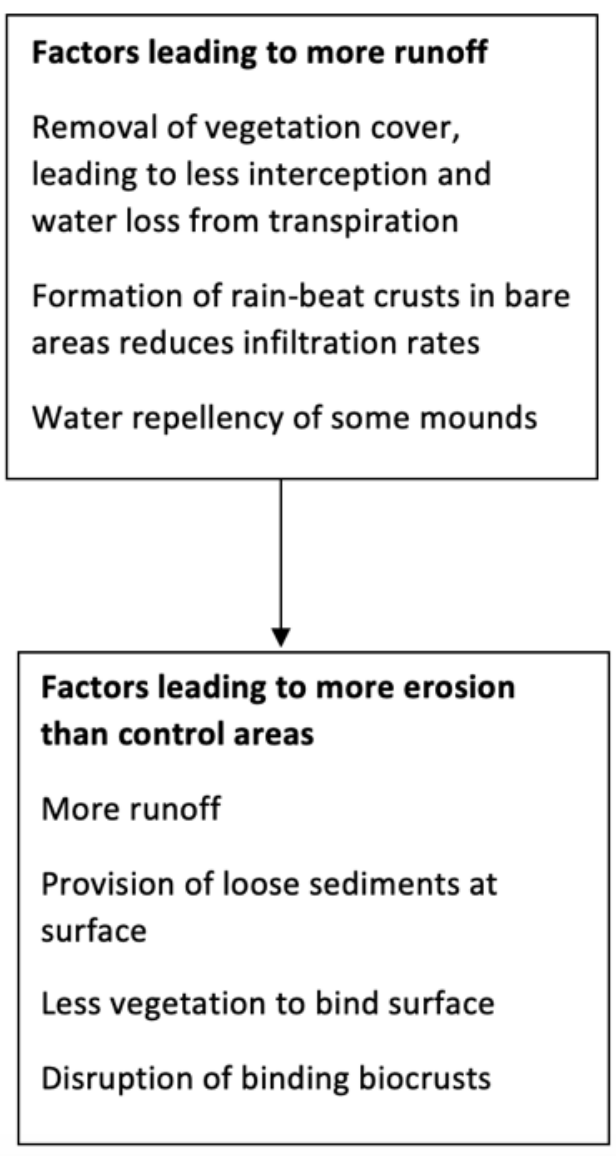

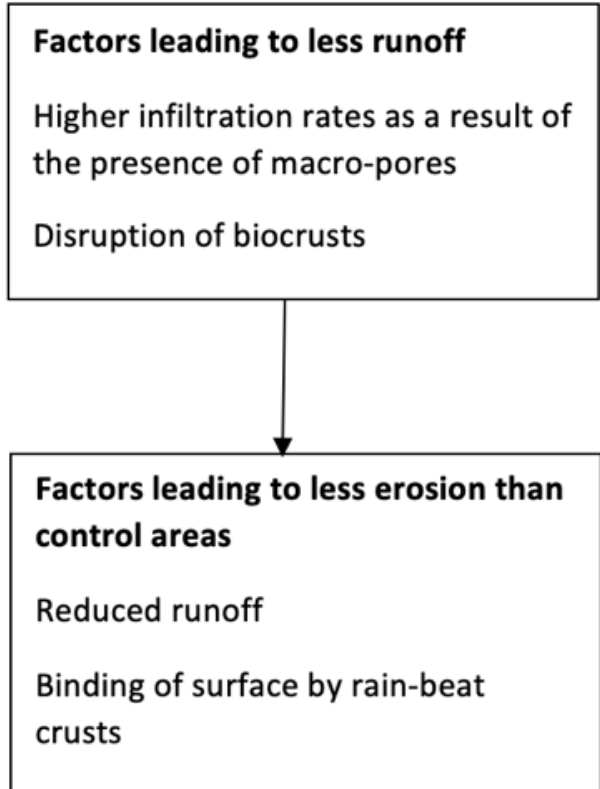

Fig.11. Factors affecting runoff and sediment movement in terrain with ants

Eldridge (1993) found that the funnel entrances of Aphaenogaster barbigula in an aeolian soil in New South Wales had steady state water infiltration rates that were 4 times those on entrance-free soils. In the Chihuahuan Desert of New Mexico, James et al. (2008) also found increased infiltration occurred due to the macropores in ant nests. Cammeraat et al. (2002), recognised that in SE Spain, Messor bouvieri could affect infiltration characteristics by modifying water repellency, for nest mounds were found to be more repellent than surrounding areas. On the other hand, another process can work in the opposite direction in 
some localities and for some species (see, for example, the work of Leite et al. (2018) in the

507 Caatinga of NE Brazil), because the baring of the soil by ant grazing of vegetation can cause crusting to occur, which reduces infiltration rates (Cerda and Doerr 2010). Conversely, Li et al. (2014) found that in the Tengger Desert of China ants markedly enhanced infiltration by weakening biological crusts. Ant impacts on infiltration have consequences for soil profile development. Phillips (2007) notes that in some soils with argillic horizons ants facilitate vertical clay translocation (lessivage) by maintaining vertical water flow pathways that would otherwise be plugged by clay accumulation. The preferential transport of finer materials to the surface by ants also contributes to the eventual concentration of fines in the B horizon.

\subsection{Runoff and soil erosion}

Because of their effect on soil infiltration rates and on vegetation cover, ants can also have a profound influence on runoff and soil movement on slopes (Fig. 11). As discussed above, several ant species can clear large circles of vegetation around their nests, which will encourage surface runoff and soil erosion. However, in areas already cleared for cultivation, the role of ants in soil loss appears to be negligible (Aalders et al. 1989). Some ants produce a large amount of material at the ground surface that is easily moved by rainsplash and overland flow, thus promoting erosion, particularly in areas with sparse vegetation (Jia et al. 2019). They may also move their nest entrances with great frequency. This is a characteristic of the Aphaenogaster funnel ants of Australia. This species produces abundant friable nest entrances - as many as 88,000 per hectare in one plot in eastern Australia (Richards 2009) and their rates of mounding amount to $0.28-8.41 \mathrm{t} \mathrm{ha}^{-1} \mathrm{yr}^{-1}$.

527 Rainfall simulation experiments in Spain by Cerda and Jurgensen (2008) showed that runoff coefficients under areas with ants were much higher than those in control areas. Cerda et al. (2009) reported rainfall simulation experiments in eastern Spain which showed that sediment 
concentrations in runoff for ant mound plots were 300\% higher than those for control plots, and that average soil erosion rates were $41 \mathrm{~kg} \mathrm{ha}^{-1}$ hour $^{-1}$ on ant mound plots and $13 \mathrm{~kg} \mathrm{ha}^{-1}$ hour $^{-1}$ on control plots. However, the presence of active Pogonomyrmex rugosus colonies in the Larrea tridentata (creosote bush) areas of Nevada, USA, appears to have a protective influence on the soil by fostering more infiltration and less runoff of surface water (Lei, 2000). Conversely, while higher water infiltration rates usually result in lower erosion rates, new soil brought to the surface by ant activity could increase the amounts of sediment available for splash and slopewash erosion (Cerda and Doerr 2010; Cerda and Jurgensen 2011). In the Blue Mountains of eastern Australia, runoff plot experiments showed that erosion of ant mounds was the major cause of sediment transport (Dragovich and Morris 2002). Rainfall simulation experiments in eastern Spain by Cerda and Jurgensen (2011) established that there was a rainfall intensity threshold when surface runoff is greater than the infiltration capacity of the ant macro-pores. Then the presence of ants will increase erosion rates. Schmidt et al. (2014) found that in Panama, stream suspended sediment loads were high even in a tropical rainforest where they might have been expected to be low. They attributed this to the demolition of ant mounds (produced by Ectatomma ruidum, Trachymyrmex cornetzi and Strumigenys marginiventris) by heavy rainstorms. Ants may contribute to biogenic soil creep (see, for example, Pawlik and Šamonil, 2018; Wilkinson et al., 2009; Hiemsath et al., 2002) though there is as yet little hard data to back up this supposition.

\subsection{Weathering of soil minerals}

552 Only a modest amount of work has been done to investigate the role that ants play in rock and mineral weathering, though ants are known to affect such weathering-related phenomena as 
soil $\mathrm{pH}$, water flow, organic matter accumulation and dispersal, and nutrient cycling. Their role depends on their type. Sanford et al (2009) divided ants into three types: aerator ants, decomposer ants, and compiler ants. They suggested that the aerators build complex subterranean tunnel networks that provide for soil aeration, water infiltration, and energy redistribution. The decomposers build tunnel networks in woody debris and facilitate decomposition and nutrient release by allowing bacteria, fungi, and water to penetrate wood. The compilers build thatch mounds on the ground that serve to increase soil nutrient availability and contribute to patchiness in vegetation. Soils near compiler ant nests often have higher mineralization rates of nitrogen and organic matter, even years after nest abandonment.

An early publication to approach this matter was by Merrill (1904, p. 204), who believed that weathering would be promoted by the organic acids from decomposing material taken into the ground by ants. He also invoked a second mechanism, whereby the underground channels excavated by ants, '...through affording easy access of air and surface waters with all their absorbed gases or alkaline salts, may serve indirectly a geological purpose scarcely inferior to that of the joints in massive rock'. Branner (1895) believed that these channels and galleries, sometimes up to $4 \mathrm{~m}$ deep, could play a role in the decomposition of rock in tropical Brazil. Dorn (2014) placed grains of plagioclase and olivine from Hawaiian basalts in ant nests in

572 Arizona and Texas, and found ants to be one of the most powerful biotic weathering agents

573 yet recognized. Dissolution rates c 60-330 times more than control rates were found in ant nests of 8 species, in comparison with c. 10-19 times for grains placed in termite mounds. potential agent of rock weathering. It is estimated that about $30 \%$ of the world's ants are

577 formicine ants. They are thus among the most numerous of the world's ants and they have large sacs containing high concentrations of formic acid. This acid functions both as a 
579 defence when sprayed and as an alarm pheromone when it is secreted. It is also used in 580 combination with tree resins to produce an antibiotic in their nests (Brütsch et al. 2017).

581 There is evidence that the amount of formic acid in proximity to ant nests is sufficient to 582 cause metal corrosion (Bastidas et al., 2006). Ants may also play a role in weathering through 583 the accumulation of soil material in cracks and joints within rocks exposed at the surface, 584 which may influence physical weathering through 'dirt cracking' and other mechanisms 585 (Ollier 1965, Dorn 2011).

586 Given the sheer mass of ant colonies that exist on Earth, improved understanding of the 587 interactions between ants, silicate minerals and carbon cycling is a potentially highly important research area (Whitchurch 2014). In this connection, ants are particularly important in carbon cycling in boreal forests, which occupy $11 \%$ of the Earth's terrestrial surface and store more $\mathrm{C}$ than any other forest biome (Wardle et al. 2011).

\section{Discussion and conclusions}

592 Although much research has probably been conducted in areas where the activities of ants are prominent, and so tends to lead to an exaggeration of their role, it is clear from the many studies which have been reviewed here, that many ants are important ecosystem engineers capable of influencing landforms and land-forming processes in a variety of ways. As we document in this paper, much data has been collected from Europe, North and South America and Australia in particular. Ant mounds built by a range of species in a broad range of environments are characteristically around $30 \mathrm{~cm}$ high and $60 \mathrm{~cm}$ in diameter (based on median values in our dataset), and ant nest depths (mainly measured in North and South America) are characteristically around $150 \mathrm{~cm}$ (based on the median value on our dataset). Densities of around ant mounds $125 \mathrm{ha}^{-1}$ are common, with maximum densities of several thousand per hectare found for species from the genus Lasius in Europe, and the genus 
Aphaenogaster in Australia. Whilst Lasius mounds are generally large and persistent, those of Aphaenogaster are small and short-lived, meaning that their net impacts on bioturbation and sediment movements are likely very different. Mound-building Lasius species are found widely across North America and Europe, whilst mound-building Aphaenogaster species are only found in Australia. From a relatively small number (25) of sets of measurements, largely from Australia, USA and Europe we find a median mounding/bioturbation rate of 1.5 tonnes $\mathrm{ha}^{-1} \mathrm{a}^{-1}$, with very high rates (over 60 tonnes $\mathrm{ha}^{-1} \mathrm{a}^{-1}$ ) recorded from Aphaenogaster longiceps in Australia and Pogonomyrmex badius in Florida, USA. Both species have narrow geographical distributions - A. longiceps found only in Australia, and P. badius only in south eastern USA. As a first order global estimate, given a median rate of ant mounding/bioturbation of 1.5 tonnes $\mathrm{ha}^{-1} \mathrm{a}^{-1}$ and assuming that this is spread across 50 million $\mathrm{km}^{2}$ (roughly the area of the globe covered by grassland and distrurbed forests, where ant action is particularly noticeable) ants may cause some $7.5 \mathrm{Gt}$ movement of sediment per year. Such a rate should be taken into account by future studies investigating the relative importance of earth movement by humans in the Anthropocene compared to that achieved by natural processes.

Whilst much quantification has already been done, there has been little attempt so far to collect field data that allows a full analysis of how the activities of ants compare with other organisms such as earthworms and termites in, for example, bioturbation. The role of ants in some geomorphological processes is very hard to assess, because of the range and complexity of impacts involved. For example, through their influence on vegetation cover ants may create patterned ground phenomena, especially in drylands, though it is not always easy, as in the case of fairy circles, to determine their role in comparison with other organisms. Ants also have an influence on soil infiltration rates, but when it comes to assessing their influence on runoff, sediment transport and soil erosion, the situation appears to be complex, and many 
factors are involved (Fig. 11). Through changes to soil chemistry in and around their nests,

629

630

631

632

633

634

635

636

637

638

639

640

641

642

643

ants may affect rates of weathering, and this is an area where a great deal more research needs to be done, particularly if we are to understand their role in global biogeochemical cycling.

Finally, as Folgarait (1998), Philpott et al. (2010) and Anderson (2019) have demonstrated, the role of ants has been modified by human activities during the Anthropocene, such as land clearance and canopy thinning (Stuhler and Orrock 2016), excavation of quarries (PeredaGomez et al. 2020), re-afforestation (Kilpeläinen et al. 2008), fire (Day et al. 2018), the conversion of savanna to rangeland (Mauda et al. 2018), grazing pressures (Nash et al. 2001; Radnan and Eldridge 2018), feral horses (Bever and Herrick 2006), the expansion of forest into grassland (Dauber et al. 2006), shrub encroachment (McAllister et al. 2014), dune stabilisation (Liu et al. 2009), disruption of biological soil crusts (Li et al. 2011) or the introduction of exotic plants (French and Major 2001). Agricultural practices such as heavy grazing, irrigation, drainage, fertilization, mowing, conventional tillage, ploughing, and reseeding, reduce ant biodiversity and/or biomass, and colony densities. Fig. 12 shows the role of land use in determining mound distribution in Oxfordshire, England.

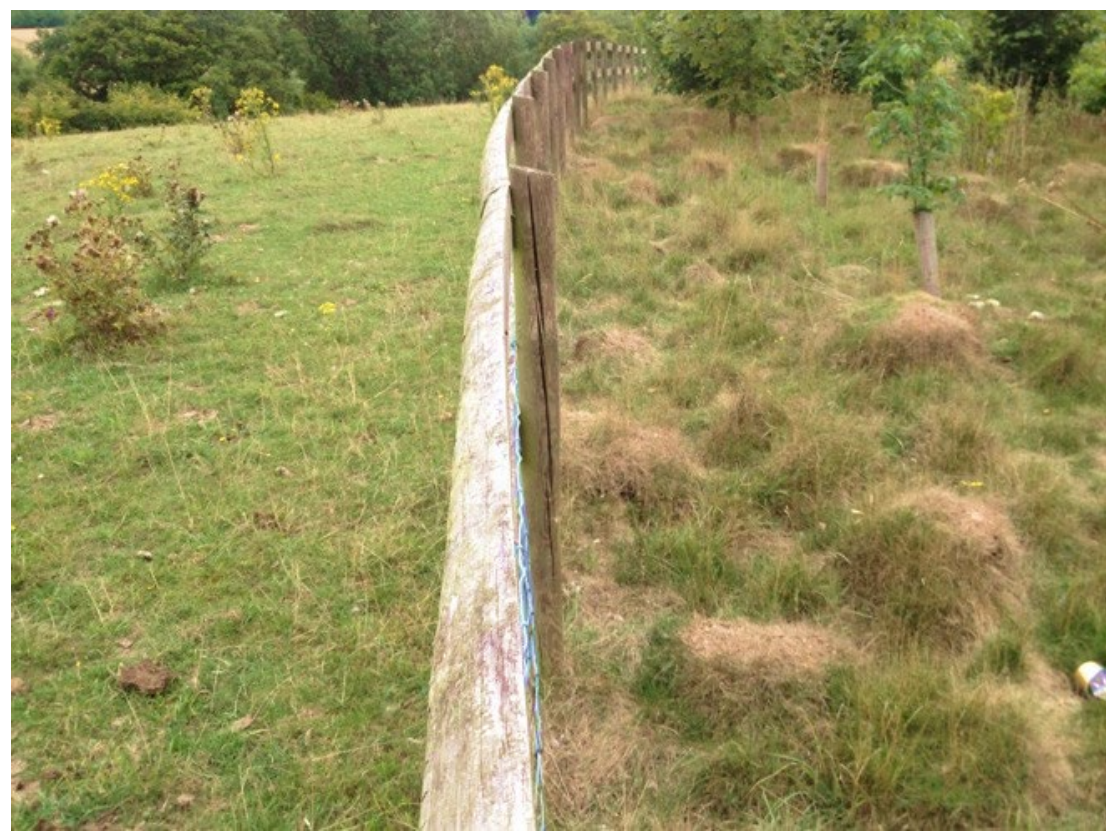


645 Fig. 12. The fenced field on the right, where grazing has been excluded to permit the establishment of a newly planted copse, has extensive Lasius flavus mound development,

647 whereas the grazed area to the left does not. The location is Wootton (near Woodstock),

648 Oxfordshire. UK. The mounds developed in just over a decade after c 2007. By November 6492019 they had largely disappeared.

650

In general it has been shown that ants exhibit a greater resistance to pollutants in comparison to other invertebrates, especially to radioactivity. Some ants have been introduced to new

652

653

654

655

656

657

658

659

660 areas by humans and have proved to be highly invasive. Owing to their small size, they can be easily transported by accident on plants, fresh products, timber, shipment containers or personal items (Bertelsmeier et al. 2016) (e.g. Myrmica rubra in New England) (Chen and Adams 2018), and the Argentinian ant Linepithema humile in the Mediterranean region (Roura-Pascual et al. 2004). Some, such as Solenopsis invicta (the fire ant) in the USA, have spread widely (Fig. 13) and have been shown to have negative impacts on native ant, invertebrate and vertebrate communities (Gotelli and Arnett 2000). Solenopsis invicta builds large mounds.

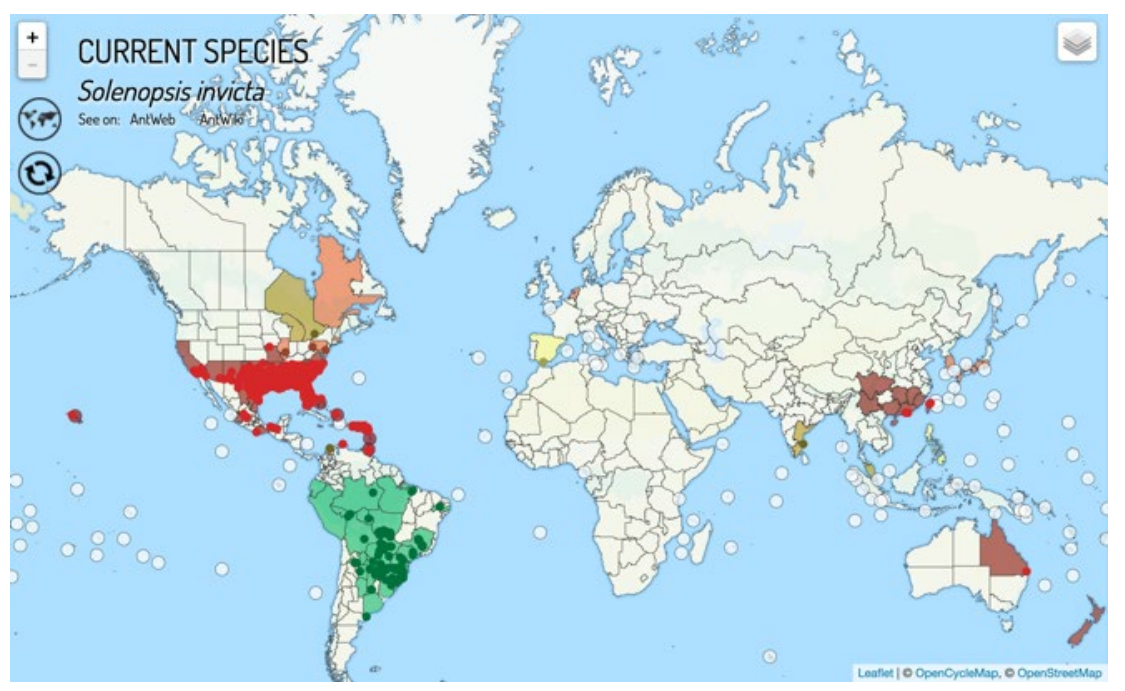

Fig.13. Global distribution of Solenopsis invicta, showing invasions (in red/brown) beyond its original range (in green) (source: AntMaps). 
663 Given this multiplicity of human impacts it is very difficult to assess how the current 664 geomorphological activities of ants compare to those when landscapes were less impacted

665

666

667

668

669

670

671

672

673

674

675

676

677

678

679

680

681

682

683

684

685

upon by humans. Ants may also be susceptible to future climate changes (Jenkins et al. 2011;

Fitzpatrick et al. 2011; Gibb et al. 2015; Wills and Landis 2018), as a result of changes in rainfall, temperatures, fire, and vegetation zonation (Botes et al. 2006), though there is some evidence that they can be tolerant of increasing drought (Hoback et al. 2020).

In conclusion, data collected from more than empirical studies on ant impacts on geomorphology from a wide array of locations around the world can be used in combination with information on the global distribution of ant species to illustrate the global impacts of ants on geomorphology. With the growth in biodiversity informatics tools such as the GABI database, further global quantification of the geomorphological roles of a wide range of species should be increasingly possible.

\section{References}

Aalders IH, Augustinus PGEF, Nobbe JM (1989) The contribution of ants to soil erosion: a reconnaissance survey. Catena 16(4-5): 449-459

Ahlbrandt TS, Andrews S, Gwynne DT (1978) Bioturbation in eolian deposits. Journal of Sedimentary Research 48(3): 839-848

Alma AM, Farji-Brener AG, Elizalde L (2020) With a little help from my friends: Individual and collaborative performance during trail clearing in leaf-cutting ants. Biotropica. doi.org/10.1111/btp.12770

Andersen AN (2019) Responses of ant communities to disturbance: Five principles for understanding the disturbance dynamics of a globally dominant faunal group. Journal of Animal Ecology 88(3): 350-362 
686 Andrews EA (1925) Growth of ant mounds. Psyche: A Journal of Entomology 32(2): 75-87

687 Andrews EA (1932) An ant hill. The Scientific Monthly, 34(2): 97-114

688 Araujo AG (2013) Bioturbation and the upward movement of sediment particles and 689 archaeological materials: comments on Bueno et al.. Journal of Archaeological Science 690 40(4): $2124-2127$

Balek CL (2002) Buried artifacts in stable upland sites and the role of bioturbation: a review.

692 Geoarchaeology 17(1): 41-51

693

Barton PS, Sato CF, Kay GM, Florance D, Lindenmayer DB (2016) Effects of

694

environmental variation and livestock grazing on ant community structure in temperate

695

eucalypt woodlands. Insect Conservation and Diversity 9(2): 124-134

696

Bastidas DM, Cayuela I, Bastidas Rull JM (2006) Ant-nest corrosion of copper tubing in air697 conditioning units. Revista de Metalurgia 42 (5): 367-381

Beever EA, Herrick JE (2006) Effects of feral horses in Great Basin landscapes on soils and ants: direct and indirect mechanisms. Journal of Arid Environments, 66(1): 96-112

Bertelsmeier C, Ollier S, Avril A, Blight O, Jourdan H, Courchamp F (2016) Colony-colony 701 interactions between highly invasive ants. Basic and Applied Ecology, 17(2): 106-114

Bétard . (2020) Insects as zoogeomorphic agents: an extended review. Earth Surface Processes and Landforms, DOI: 10.1002/esp.4944

Bierbass P, Gutknecht JL, Michalzik B (2015) Nest-mounds of the yellow meadow ant (Lasius flavus) at the "Alter Gleisberg", Central Germany: Hot or cold spots in nutrient cycling? Soil Biology and Biochemistry 80: 209-217 
Blume HP (2014) Charles Darwin and the discovery of bioturbation in the year 1837. Annals of Agrarian Science 9(1): 66-69

Botes A, McGeoch MA, Robertson HG, Van Niekerk A, Davids HP, Chown SL (2006) Ants, altitude and change in the northern Cape Floristic Region. Journal of Biogeography, 33(1): $71-90$

Branner JC (1895) Decomposition of rocks in Brazil. Bulletin of the Geological Society of America 7: 255-314

Branner JC (1900) Ants as geological agents in the tropics. Journal of Geology 8: 151-153

Branner JC (1910) Geologic work of ants in tropical America. Bulletin of the Geological Society of America, 21(1): 449-496

Bristow CM, Cappaert D, Campbell NJ, Heise A (1992) Nest structure and colony cycle of the Allegheny mound ant, Formica exsectoides Forel (Hymenoptera: Formicidae). Insectes Sociaux 39(4): 385-402

Brütsch T, Jaffuel G, Vallat A, Turlings TC, Chapuisat M (2017) Wood ants produce a potent antimicrobial agent by applying formic acid on tree-collected resin. Ecology and Evolution 7(7): 2249-2254

Buhl J, Gautrais J, Deneubourg JL, Kuntz P, Theraulaz G (2006) The growth and form of tunnelling networks in ants. Journal of Theoretical Biology 243(3): 287-298

Burchill AT, Moreau CS (2016) Colony size evolution in ants: macroevolutionary trends. Insectes Sociaux 63(2): 291-298

727 Cammeraat ELH, Risch AC (2008) The impact of ants on mineral soil properties and processes at different spatial scales. Journal of Applied Entomology 32(4): 285-294 
729 Cammeraat LH, Willott SJ, Compton SG, Incoll LD (2002) The effects of ants' nests on the 730 physical, chemical and hydrological properties of a rangeland soil in semi-arid Spain.

731 Geoderma 105(1): 1-20

732 Carlson SR, Whitford WG (1991) Ant mound influence on vegetation and soils in a semiarid 733 mountain ecosystem. American Midland Naturalist, 126: 125-139

Cerdà A, Doerr SH (2010) The effect of ant mounds on overland flow and soil erodibility following a wildfire in eastern Spain. Ecohydrology 3(4): 392-401

Cerdà A, Jurgensen MF (2008) The influence of ants on soil and water losses from an orange orchard in eastern Spain. Journal of Applied Entomology 132(4): 306-314

Cerdà A, Jurgensen MF (2011) Ant mounds as a source of sediment on citrus orchard plantations in eastern Spain. A three-scale rainfall simulation approach. Catena 85(3): 231236

Cerdà A, Jurgensen M, Bodi M (2009) Effects of ants on water and soil losses from organically-managed citrus orchards in eastern Spain. Biologia, 64(3): 527-531

Chen W, Adams ES (2018) The distribution and habitat affinities of the invasive ant Myrmica rubra (Hymenoptera: Formicidae) in Southern New England. Environmental Entomology, 47(3): 527-534

746 Conway JR (1996) A field study of the nesting ecology of the thatching ant Formica obscuripes Forel, at high altitude in Colorado. The Great Basin Naturalist, 56: 326-332 significant global geomorphological driving force of the 21st century. The Anthropocene

$750 \quad$ Review, 5(3): 222-229 
751 Cosarinsky MI, Roces F (2012) The construction of turrets for nest ventilation in the grass752 cutting ant Atta vollenweideri: import and assembly of building materials. Journal of Insect 753 Behavior, 25(3): 222-241

754 Cosarinsky MI, Römer D, Roces F (2020) Nest turrets of Acromyrmex grass-cutting ants: 755 Micromorphology reveals building techniques and construction dynamics. Insects, 11(2): 140 Cowan JA, Humphreys GS, Mitchell PB, Murphy CL (1985) An assessment of pedoturbation by two species of mound-building ants, Camponotus intrepidus (Kirby) and Iridomyrmex purpureus (F. Smith). Soil Research, 23(1): 95-107 reassessment based on the evidence from the sites of Doel and Verrebroek (Belgium). Journal of Archaeological Science, 61: 158-171

Czaczkes TJ, Ratnieks FL (2013) Cooperative transport in ants (Hymenoptera: Formicidae) and elsewhere. Myrmecological News, 18, 1-11

Darlington J (2007) Arena nests built by termites in the Masai Mara, Kenya. Journal of East African Natural History, 96(1): 73-81

Dauber J, Bengtsson JAN, Lenoir L (2006). Evaluating effects of habitat loss and land-use continuity on ant species richness in seminatural grassland remnants. Conservation Biology, 20(4): 1150-1160

Day JD, Bishop TB, St. Clair SB (2018) Fire and plant invasion, but not rodents, alter ant community abundance and diversity in a semi-arid desert. Ecosphere, 9(7): p.e02344 Arid Environments, 25(2): 249-260 
Dean WRJ, Milton SJ, Klotz S (1997) The role of ant nest-mounds in maintaining small-scale patchiness in dry grasslands in Central Germany. Biodiversity and Conservation, 6(9): 12931307

Dibner RR, Doak DF, Lombardi EM (2015) An ecological engineer maintains consistent spatial patterning, with implications for community-wide effects. Ecosphere, 6(9): 1-17

Dorn RI (2011) Revisiting dirt cracking as a physical weathering process in warm deserts. Geomorphology, 135(1-2): 129-142

Dorn RI (2014) Ants as a powerful biotic agent of olivine and plagioclase dissolution. Geology, 42(9): 771-774

Dostál P, Březnová M, Kozlíčková V, Herben T, Kovář P (2005) Ant-induced soil modification and its effect on plant below-ground biomass. Pedobiologia, 49(2): 127-137

Drager KI, Hirmas DR, Hasiotis ST (2016) Effects of ant (Formica subsericea) nests on physical and hydrological properties of a fine-textured soil. Soil Science Society of America Journal, 80(2): 364-375.

Dragovich D, Morris R (2002) Fire intensity, slopewash and bio-transfer of sediment in eucalypt forest, Australia. Earth Surface Processes and Landforms, 27(12): 1309-1319

Dreyer WA (1942) Further observations on the occurrence and size of ant mounds with reference to their age. Ecology, 23(4): 486-490

Drummond F, Choate B (2011) Ants as biological control agents in agricultural cropping systems. Terrestrial Arthropod Reviews, 4(2): 157-180

Dugas DP (2001) The influence of arroyo edges on Pogonomyrmex rugosus nest distribution in the Chihuahuan Desert, New Mexico. Journal of Arid Environments, 47(2): 153-159 

macroevolution of the latitudinal diversity gradient in ants. Nature Communications, 9(1): 18.

Eldridge DJ (1993) Effect of ants on sandy soils in semi-arid eastern Australia - Local distribution of nest entrances and their effect on infiltration of water. Soil Research, 31(4): $509-518$

Feinerman O, Pinkoviezky I, Gelblum A, Fonio E, Gov NS (2018) The physics of cooperative transport in groups of ants. Nature Physics, 14(7): 683.-693 the future of biodiversity: a test of single-and multi-species models for ants in North America. Ecography, 34(5): 836-847

Folgarait PJ (1998) Ant biodiversity and its relationship to ecosystem functioning: a review. Biodiversity and Conservation, 7(9): 1221-1244

Franks NR, Britton NF, Sendova-Franks AB, Denny AJ, Soans EL, Brown AP, Cole RE, Havardi RJ, Griffiths CJ, Ellis SR (2004) Centrifugal waste disposal and the optimization of ant nest craters. Animal Behaviour, 67(5): 965-973

French K, Major RE (2001) Effect of an exotic Acacia (Fabaceae) on ant assemblages in

813 South African fynbos. Austral Ecology, 26(4): 303-310

Gabet EJ, Reichman OJ, Seabloom EW (2003) The effects of bioturbation on soil processes and sediment transport. Annual Review of Earth and Planetary Science, 31(1): 249-273

816 Gautrais J, Buhl J, Valverde S, Kuntz P, Theraulaz G (2014) The role of colony size on

817 tunnel branching morphogenesis in ant nests. PLoS ONE, 9(10): e109436. 
819 Genise JF (2017) Ichnoentomology: Insect Traces in Soils and Paleosols. Springer Nature,

820 Cham

821 Getzin S, Yizhaq H, Cramer MD, Tschinkel WR (2019) Contrasting global patterns of

822 spatially periodic fairy circles and regular insect nests in drylands. Journal of Geophysical

823 Research: Biogeosciences, 124(11): 3327-3342

824 Ghobadi M, Mahdavi M, Agosti D (2016) Changes in soil properties by harvester ant's

825 activity (Messor spp.) in Roodshoor Steppe Rangeland of Saveh, Iran. Journal of Rangeland

826 Science, 6(3): 273-285

827 Gibb H, Sanders NJ, Dunn RR, Watson S, Photakis M, Abril S, Andersen AN, Angulo E,

828 Armbrecht I, Arnan X, Baccaro FB (2015) Climate mediates the effects of disturbance on ant

829 assemblage structure. Proceedings of the Royal Society B: Biological Sciences, 282(1808):

$830 \quad$ p.20150418

831 Giraud T, Pedersen JS, Keller L (2002) Evolution of supercolonies: the Argentine ants of

832 southern Europe. Proceedings of the National Academy of Sciences, 99(9): 6075-6079

833 Gotelli NJ, Arnett AE (2000) Biogeographic effects of red fire ant invasion. Ecology

834 Letters, 3(4): 257-261

835 Goudie AS (1988) The geomorphological role of termites and earthworms in the tropics. In:

836 Viles HA (ed) Biogeomorphology. Blackwell, Oxford, 166-192

837 Graedel TE, Eisner T (1988) Atmospheric formic acid from formicine ants: a preliminary

838 assessment. Tellus B, 40(5): 335-339

839 Green WP, Pettry DE, Switzer RE (1999) Structure and hydrology of mounds of the imported

840 fire ants in the southeastern United States. Geoderma, 93(1): 1-17 
842 Biodiversity Informatics (GABI) database: a synthesis of ant species geographic

843 distributions. Myrmecological News, 24: 83-89.

844 Halboth F, Roces, F (2017) The construction of ventilation turrets in Atta vollenweideri leaf845 cutting ants: Carbon dioxide levels in the nest tunnels, but not airflow or air humidity,

846 influence turret structure. PloS ONE, 12(11): p.e0188162

847 Heimsath AM, Chappell J, Spooner NA, Questiaux DG (2002) Creeping

848 soil. Geology, 30(2): 111-114

849 Henderson G, Wagner RO, Jeanne RL (1989) Prairie ant colony longevity and mound 850 growth. Psyche: A Journal of Entomology, 96(3-4): 257-268

851 Hoback WW, Jurzenski J, Farnsworth-Hoback KM, Roeder KA (2020) Invasive saltcedar 852 and drought impact ant communities and isopods in South-Central Nebraska. Environmental 853 Entomology, 49(3): 607-614

854 James AI, Eldridge DJ, Koen TB, Whitford WG (2008) Landscape position moderates how 855 ant nests affect hydrology and soil chemistry across a Chihuahuan Desert watershed. 856 Landscape Ecology, 23(8): 961-975

857 Jenkins CN, Sanders NJ, Andersen AN, Arnan X, Brühl CA, Cerda X, Ellison AM, Fisher 858 BL, Fitzpatrick MC, Gotelli NJ, Gove AD (2011) Global diversity in light of climate change: 859 the case of ants. Diversity and Distributions, 17(4): 652-662 Jia Y, Li T, Shao MA, Shen N (2019) Camponotus japonicus burrowing activities exacerbate soil erosion on bare slopes. Geoderma, 348: 158-167

862 Johnson D (1990) Biomantle evolution and the redistribution of earth materials and artifacts. Soil Science, 149(2): 84-102 
Kilpeläinen J, Punttila P, Finér L, Niemelä P, Domisch T, Jurgensen MF, Neuvonen S,

871 Ohashi M, Risch AC, Sundström L (2008) Distribution of ant species and mounds (Formica)

872 in different-aged managed spruce stands in eastern Finland. Journal of Applied

873 Entomology, 132(4): 315-325

874 Kinahan GH (1869) IV.- Additional notes on the growth of soil. Geological Magazin,e $875 \quad 6(62): 348-351$

876 King JR, (2016) Where do eusocial insects fit into soil food webs? Soil Biology and 877 Biochemistry, 102: 55-62

878 King JR, Warren RJ, Bradford MA (2013) Social insects dominate eastern US temperate 879 hardwood forest macroinvertebrate communities in warmer regions. PLoS ONE, 8(10): p.e75843

881 King TJ (1981a) Ant-hills and grassland history. Journal of Biogeography, 8: 329-334 King TJ (1981b) Ant-hill vegetation in acidic grasslands in the Gower Peninsula, South Wales. New Phytologist, 88(3): 559-571

884 Klimetzek D (1981) Population studies on hill building wood-ants of the Formica rufa885 group. Oecologia, 48(3): 418-421 
Lach L, Parr C, Abbott K (2010) Ant Ecology. Oxford, Oxford University Press

Lei SA (2000) Ecological impacts of seed harvester ants on soil attributes in a Larreadominated shrubland. Western North American Naturalist, 60: 439-444

Leite PA, Carvalho MC, Wilcox BP (2018) Good ant, bad ant? Soil engineering by ants in 895 the Brazilian Caatinga differs by species. Geoderma, 323: 65-73

Leonard KC(2001) Post-Glacial ant generated desert pavements in Southeastern Oregon.

Lesica P, Kannowski PB (1998) Ants create hummocks and alter structure and vegetation of a Montana fen. American Midland Naturalist, 139(1): 58-68 moisture cannot be neglected in the northern Loess Plateau. Agriculture, Ecosystems \&

902 Environment, 239: 182-187

Li TC, Shao, MA, Jia YH, Jia XX, Huang LM, Gan M (2019) Small-scale observation on the effects of burrowing activities of ants on soil hydraulic processes. European Journal of Soil Science, 70(2): 236-244 successional stages of biological soil crusts in the Tengger Desert, Northern China. Applied Soil Ecology, 47(1): 59-66 
Li XR, GaoYH, Su JQ, Jia RL, Zhang ZS (2014) Ants mediate soil water in arid desert ecosystems: Mitigating rainfall interception induced by biological soil crusts? Applied Soil

911 Ecology, 78: 57-64

912 Liu RT, Zhao HL, Zhao XY (2009) Effect of vegetation restoration on ant nest-building 913 activities following mobile dune stabilization in the Horqin Sandy land, Northern

914 China. Land Degradation \& Development, 20(5): 562-571

915 Lobry de Bruyn L, Conacher AJ (1990) The role of termites and ants in soil modification-a 916 review. Soil Research, 28(1): 55-93

917 Lyford WH (1963) Importance of ants to brown podzolic soil genesis in New England.

918 Harvard Forest Paper 7: 1-18

919 íMcAllister MM, Schooley R., Bestelmeyer BT, Coffman JM, Cosentino BJ (2014) Effects of 920 grassland restoration efforts on mound-building ants in the Chihuahuan Desert. Journal of 921 Arid Environments, 111: 79-83

MacMahon JA, Mull JF, Crist TO (2000) Harvester ants (Pogonomyrmex spp.): their community and ecosystem influences. Annual Review of Ecological Systematics, 31: 265291 ant diversity, assemblage composition and dominant functional groups in African savannas. Biodiversity and Conservation, 27(4): 947-965

McCook HC (1877) Mound-making ants of the Alleghenies, their architecture and habits.

930 McCook HC (1909) Ant Communities and how they are Governed: A Study in Civics. New 
932 Merrill GP (1904) Rocks, Rock Weathering and Soils. New York, Macmillan

933

934 of the Entomological Society of America, 99(5): 891-897

935 Nash MS, Whitford WG, Bradford DF, Franson SE, Neale AC, Heggem DT (2001) Ant

936 communities and livestock grazing in the Great Basin, USA. Journal of Arid

937 Environments, 49(4): 695-710

938 Ollier CD (1965) Dirt cracking - a type of insolation weathering. Australian Journal of

939 Science, 27(8): 236-237

940

$941 \quad$ Press

942 Pawlik $Ł$, Šamonil P (2018) Soil creep: the driving factors, evidence and significance for

943 biogeomorphic and pedogenic domains and systems-a critical literature review. Earth-

944 Science Reviews, 178: 257-278

945 Pereda-Gomez ME, Pessacq P, Elizalde L (2020) Stress-tolerant ants and the impact of

946 quarries on an ant community in Patagonia. Journal of Arid Environments, 173: p.104017

947 Phillips HR and 132 others (2019) Global distribution of earthworm activity. Science, 366:

$948 \quad 480-485$

949 Phillips JD (1999) Edge effects in geomorphology. Physical Geography, 20(1): 53-66

950 Phillips JD (2007) Formation of texture contrast soils by a combination of bioturbation and 951 translocation. Catena, 70: 92-104

952

Philpott SM, Perfecto I, Armbrecht I, Parr CL (2010) Ant diversity and function in disturbed 
954 Picker MD, Ross-Gillespie VERE, Vlieghe K, Moll E (2012) Ants and the enigmatic

955 Namibian fairy circles-cause and effect? Ecological Entomology, 37(1): 33-42

956 Pitt W (1809) General View of the Agriculture of the County of Northampton. London, R

957 Phillips

958 Porter SD, Jorgensen CD (1988) Longevity of harvester ant colonies in southern Idaho.

959 Journal of Range Management, 41(2): 104-107

960 Rabeling C, Verhaagh M, Engels W (2007) Comparative study of nest architecture and 961 colony structure of the fungus-growing ants, Mycocepurus goeldii and M. smithii. Journal of 962 Insect Science, 7(1): 1-13

963 Radnan GN, Eldridge DJ (2018) Ants respond more strongly to grazing than changes in shrub 964 cover. Land Degradation \& Development, 29(4): 907-915

965 Richards PJ (2009) Aphaenogaster ants as bioturbators: Impacts on soil and slope processes.

966 Earth-Science Reviews, 96(1): 92-106

967 Richards PJ, Humphreys GS, Tomkins KM, Shakesby RA, Doerr SH (2011) Bioturbation on 968 wildfire-affected southeast Australian hillslopes: spatial and temporal variation. Catena, 969 87(1): 20-30

970 Rink WJ, Dunbar JS, Tschinkel WR, Kwapich C, Repp A, Stanton W, Thulman DK (2013)

971 Subterranean transport and deposition of quartz by ants in sandy sites relevant to age

972 overestimation in optical luminescence dating. Journal of Archaeological Science, 40(4):

$973 \quad 2217-2226$

974 Robins R, Robins A (2011) The antics of ants: ants as agents of bioturbation in a midden 975 deposit in south-east Queensland. Environmental Archaeology, 16(2): 151-161 
977 Geographical potential of Argentine ants (Linepithema humile Mayr) in the face of global

978 climate change. Proceedings of the Royal Society of London. Series B: Biological

979 Sciences, 271(1557): 2527-2535

980 Sanford MP, Manley PN, Murphy DD (2009) Effects of urban development on ant

981 communities: implications for ecosystem services and management. Conservation

982 Biology, 23(1): 131-141

983 Schmidt LK, Zimmermann A, Elsenbeer H (2014) Ant mounds as a source of sediment in a tropical rainforest? Hydrological Processes, 28(13): 4156-4160

Schoville BJ, Burris LE, Todd LC, (2009) Experimental artifact transport by harvester ants (Pogonomyrmex sp.): Implications for patterns in the archaeological record. Journal of Taphonomy, 7(4): 285-303

Scott HW, (1951) The geological work of the mound-building ants in western United

990 Schultz TR, (2000) In search of ant ancestors. Proceedings of the National Academy of

Sciences, 97(26): 14028-14029 Office.

Sharp LA, Barr WF (1960) Preliminary investigations of harvester ants on southern Idaho rangelands. Journal of Range Management, 13: 131-134

Smith JJ, Platt BF, Ludvigson GA, Thomasson JR (2011) Ant-nest ichnofossils in

997 honeycomb calcretes, Neogene Ogallala Formation, High Plains region of western Kansas, 
999 Sneva FA (1979) The western harvester ants: their density and hill size in relation to herbaceous productivity and big sagebrush cover. Rangeland Ecology \&

1001 Management/Journal of Range Management Archives, 32(1): 46-47

1002

Soule PT, Knapp PA (1996) The influence of vegetation removal by western harvester ants

1003 (Pogonomyrmex owyheei) in a relict area of sagebrush-steppe in central Oregon. American 1004 Midland Naturalist, 136: 336-345

1005

Spangler HG, Rettenmeyer CW, (1966) The function of the ammochaetae or psammophores 1006 of Harvester ants, Pogonomyrmex spp. Journal of the Kansas Entomological Society, 39:

1007 $739-745$

1008

Sparavigna AC (2016a) Patterned vegetation created by Red Harvester ants and evidenced in 1009 satellite images. hal-01289240

1010 Sparavigna A (2016b) Patterned vegetation created by ants and observed in satellite images 1011 of Arizona. PHILICA, 2016, 1-3. ISSN 1751-3030

1012

Stuhler JD, Orrock JL (2016) Historical land use and present-day canopy thinning differentially affect the distribution and abundance of invasive and native ant species. Biological Invasions, 18(7): 1813-1825

1015

Swanson AC, Schwendenmann L, Allen MF, Aronson EL, Artavia-León A, Dierick D, Fernandez-Bou AS, Harmon TC, Murillo-Cruz C, Oberbauer SF, Pinto-Tomás AA (2019)

Welcome to the Atta world: A framework for understanding the effects of leaf-cutter ants on 1018 ecosystem functions. Functional Ecology, 33(8); 1386-1399

1019

Syvitski JP, Kettner A (2011) Sediment flux and the Anthropocene. Philosophical Transactions of the Royal Society A: Mathematical, Physical and Engineering

1021 Sciences, 369(1938): 957-975. 
1022 Taylor AR, Lenoir L, Vegerfors B, Persson T (2019) Ant and earthworm bioturbation in 1023 cold-temperate ecosystems. Ecosystems, 22(5): 981-994

1024 Thorp J, (1949) Effects of certain animals that live in soils. Scientific Monthly, 68(3): 1801025191

1026 Tschinkel WR (2005) The nest architecture of the ant, Camponotus socius. Journal of Insect 1027 Science, 5(1): 9

1028 Tschinkel WR (2015) Biomantling and bioturbation by colonies of the Florida harvester ant, 1029 Pogonomyrmex badius. PloS ONE, 10(3): p.e0120407

1030 Tschinkel WR, Seal JN (2016) Bioturbation by the fungus-gardening ant, Trachymyrmex 1031 septentrionalis. PloS ONE, 11(7): p.e0158920

1032 Tuma J, Eggleton P, Fayle TM (2020) Ant-termite interactions: an important but under1033 explored ecological linkage. Biological Reviews, 95(3): 555-572

1034 Waloff N, Blackith RE (1962) The growth and distribution of the mounds of Lasius flavus 1035 (Fabricius) (Hym: Formicidae) in Silwood Park, Berkshire. Journal of Animal Ecology, $1036 \quad 31(2): 421-437$ Ward PS (2014) The phylogeny and evolution of ants. Annual Review of Ecology, Evolution, 1038 and Systematics, 45: 23-43

Wardle DA, Hyodo F, Bardgett RD, Yeates GW, Nilsson MC (2011) Long-term aboveground and belowground consequences of red wood ant exclusion in boreal 1041 forest. Ecology, 92(3): 645-656

1042 Wheeler GC, Wheeler J (1983) The superstructures of ant nests (Hymenoptera: 1043 Formicidae). Transactions of the American Entomological Society, 109(2), 159-177 
1045 Whitford WG, Eldridge DJ (2013) Effects of ants and termites on soil and geomorphological 1046 processes. In: Butler DR and Hupp CR (eds.), Ecogeomorphology, Vol 12 of the Treatise in 1047 Geomorphology. Academic Press, San Diego, 281-292

1048 Wills BD, Landis DA (2018) The role of ants in north temperate grasslands: a

1049 review. Oecologia, 186(2): 323-338

1050 Wilkinson MT, Richards PJ, Humphreys GS (2009) Breaking ground: pedological, 1051 geological, and ecological implications of soil bioturbation. Earth-Science Reviews, 97(1): $1052 \quad 257-272$

1053 Wilson EO, Carpenter FM, Brown WL (1967) The first Mesozoic ants. Science, 157(3792): $1054 \quad 1038-1040$

1055

1056

1057

1058 